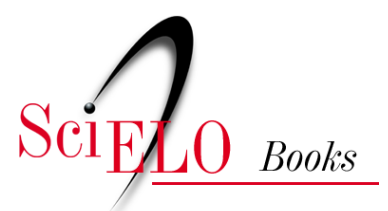

EDITORA

\title{
Cidades novas e seus conceitos
}

\author{
Ricardo Trevisan
}

\section{SciELO Books / SciELO Livros / SciELO Libros}

TREVISA, R. Cidades novas e seus conceitos. In: Cidades novas [online]. Brasília: Editora UnB, 2020, pp. 55-101. Pesquisa, inovação \& ousadia series. ISBN: 978-65-5846-158-6. https://doi.org/10.7476/9786558461586.0005.

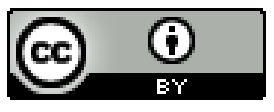

All the contents of this work, except where otherwise noted, is licensed under a $\underline{\text { Creative }}$ Commons Attribution 4.0 International license.

Todo o conteúdo deste trabalho, exceto quando houver ressalva, é publicado sob a licença Creative Commons Atribição 4.0.

Todo el contenido de esta obra, excepto donde se indique lo contrario, está bajo licencia de la licencia Creative Commons Reconocimento 4.0. 


\section{Cidades novas e seus conceitos}

\section{Conexão: Santos, São Paulo.}

Contemporaneamente ao sonho realizado em terras mineiras, a secular vila portuária de Santos, fundada no litoral paulista em 1545, recebe, pelos preceitos da engenharia sanitarista, um novo plano urbano, um plano de modernização que a transformou em uma nova cidade. Um cenário fervilhante, desenhado a partir das últimas décadas do século XIX, quando a cidade se destacava por sua posição estratégica e, concomitantemente, como o principal porto brasileiro na exportação cafeeira e a porta de entrada para milhares de imigrantes.

O ouro verde, escoado por ferrovias vindas do interior, chegava à cidadela empresarial de Paranapiacaba, ${ }^{1}$ descendo a Serra do Mar até chegar ao porto da Companhia Docas de Santos. Na mão inversa, italianos, poloneses, judeus, alemães, espanhóis, japoneses, árabes e mesmo brasileiros de outras regiões desembarcavam em terra firme, deparando-se com imagens de uma cidade em franco crescimento socioeconômico.

Todavia, era uma paisagem caótica, babélica, espurcícia, sem condições de atender adequadamente ao contingente populacional que ali chegava. Um cenário composto por frequentes surtos epidêmicos e pelo aumento gradativo do déficit

\footnotetext{
Paranapiacaba surgiu em 1867 como uma CN empresarial, empreendida pela The Sao Paulo Railway Company Ltd. e implantada à borda da Serra do Mar. A vila foi criada para abrigar funcionários e respectivos familiares que trabalhavam para a Companhia (de capital inglês) responsável pela administração e funcionamento da linha férrea San Paulo Railway. Assim como nas company towns (cidades empresariais), a vila apresentava uma setorização primária (áreas produtivas e áreas de repouso), ruas largas e pavimentadas com paralelepípedos, infraestrutura básica, habitações isoladas no lote - padronizadas de acordo com o número de moradores (à exceção das casas dos diretores) - e equipamentos sociais voltados para ações culturais e de lazer de seus habitantes. Hoje, a vila é distrito do município de Santo André, no ABC paulista, tombada em 2008 pelo Instituto do Patrimônio Artístico e Histórico Nacional - Iphan.
} 
habitacional, frutos de um crescimento rápido e repentino - a população local saltou de 15 mil habitantes em 1886 para cerca de 50 mil em 1900.

Localizada numa planície peninsular, separada da vila de São Vicente (1532) por elevações naturais, isolada pela baía e pelo canal de Santos, a cidade precisava adequar-se às novas funções às quais estava exposta assim como sanear seus espaços físicos. Um ambiente degradado que demandava, urgentemente, do governo municipal e estadual, ações reparadoras.

As ações visavam, de modo geral, a garantir à cidade condições básicas de infraestrutura: saneamento, energia, transporte público (bonde) e sistema viário adequado. As epidemias que assolavam a saúde pública nesse momento seriam solucionadas com a construção de redes públicas de abastecimento de água e coleta de esgoto da maneira proposta por médicos-higienistas e engenheiros-sanitaristas. As estreitas vias não mais comportavam o tráfego de veículos e pedestres; era necessário discipliná-las e aumentar a capacidade de fluxo mediante projetos para o sistema viário - novo alinhamento para os edifícios; abertura, alargamento e prolongamento de vias; desenho de canteiros centrais etc. Assim, expandir o traçado urbano por meio de planos de saneamento, melhoramentos e extensão, rumo a uma ocupação ordenada da península, foi a solução encontrada.

Segundo José Marques Carriço (2013), as obras de saneamento e melhoramentos começaram com a reforma do cais do porto em 1888, seguida pela construção da primeira rede de esgoto - baseada no sistema de separação parcial, com águas cloacais e pluviais conduzidas por uma mesma rede. Obras sucedidas por planos de saneamento e leis específicas: o plano de $1892,{ }^{2}$ elaborado pelo engenheiro civil

2 Mesmo ano de fundação da CN balneária do Guarujá, vizinha a Santos, primeiro grande plano imobiliário para o lazer realizado no estado de São Paulo e sob a responsabilidade da Companhia Balneária da Ilha de Santo Amaro (REIS FILHO, 1994; MARINO, 2017). O plano urbanístico e arquitetônico coube ao engenheiro civil Elias Fausto Jordão Pacheco (1849-1901). Formado pela Faculdade de Cornell (EUA), Pacheco trabalhou para a Companhia Paulista de Estradas de Ferro e para a Companhia Ituana antes de assumir o plano para o balneário. Tomou como referência os projetos de CNs norte-americanas das regiões pioneiras e de alguns empreendimentos urbanísticos mais sofisticados da região de Rhode Island. Como consequência, verificou-se um núcleo construído sob os moldes da arquitetura e do urbanismo anglo-saxão. Paralela à orla marítima, foram 
porto-riquenho Estevan Antonio Fuertes (1838-1903), então professor de engenharia sanitária na Universidade de Cornell (EUA); o Código de Posturas Municipal e o Código Sanitário Estadual, ambos de 1893; e os planos das comissões: Thomas Cochrane, de 1896, e Alfredo Lisboa, de 1897. Em 1898, foram criadas as repartições de Águas e Esgotos da capital paulista e Técnica de Águas e Esgotos do Estado. No mesmo ano, ambas foram unificadas na repartição de Águas e Esgotos, sob a chefia do engenheiro sanitarista baiano Theodoro Sampaio (1855-1937).

Ademais, o primeiro plano de expansão para Santos surgiu apenas em 1896, encomendado pela Câmara Municipal e atribuído ao engenheiro José Brant de Carvalho (1856-1917). Um plano elementar, no qual o autor expandia até a barra uma malha cardo-decumano (vias no sentido norte-sul e leste-oeste) a partir do antigo núcleo. Partido projetual indicado para um terreno relativamente plano, com quadras regulares pontuadas por praças equidistantes. Nota-se, entretanto, que não houve preocupação em adequar as vias aos caminhos pré-existentes nem diferenciá-las paisagisticamente ou mesmo em considerar os seus aspectos hidrológicos.

Esse conjunto de planos, obras e leis pouco contribuíram para uma solução definitiva. Somente no início do século XX ocorreria uma alteração nesse quadro, com a organização, em 1903, da Comissão de Saneamento do Estado de São Paulo, dirigida, inicialmente, pelo engenheiro José Pereira Rebouças (1856-ignoto). Dois anos mais tarde, o cargo de chefia passa à responsabilidade do engenheiro sanitarista Francisco Saturnino Rodrigues de Brito (1864-1929), nascido no Rio de Janeiro e formado pela mesma Escola Politécnica de Aarão Reis.

Assim como Reis, Saturnino de Brito também foi seguidor dos ideais positivistas, acreditando ser a ciência a solução para os problemas cotidianos. Antes de Santos, o sanitarista já havia aplicado seus conhecimentos técnicos em projetos para: Piracicaba (1893); Belo Horizonte (1894-1895, tendo contato com Aarão Reis);

implantadas, em sequência, uma faixa de jardim e os principais edifícios (Grande Hotel, cassino etc.); perpendicularmente, encontravam-se a linha férrea (ramificação da San Paulo Railway alocada em Santos), a principal via e a igreja. Todos os edifícios, inclusive as 46 casas em estilo Bungalow (chalés), foram projetados e construídos com madeiras importadas do estado da Geórgia, EUA. 
Novo Arrabalde em Vitória (1896); Campinas, Ribeirão Preto, Limeira, Sorocaba e Amparo (entre 1896-1897); Petrópolis (1898); Campos (1902-1903); e outros. Eram estudos higienizadores, visando a sanear as cidades com rede de abastecimento de água e sistemas para coleta de esgotos e drenagem de águas pluviais, usufruindo de novos saberes e novas técnicas construtivas, como, por exemplo, o uso do concreto armado na confecção de canais fechados e abertos.

Paralelamente, podemos relacionar as propostas urbanas de Brito com as teorias formuladas por Camillo Sitte em sua Cidade artística (1889). Embora distantes e vivenciando realidades diferenciadas, ambos defendiam a estética urbana "na concepção organicista da cidade, que [os levava] a privilegiar os chamados planos gerais ou de conjunto” (ANDRADE, 1992, p. 208). Uma maneira de pensar a cidade como um todo, aliada à possibilidade de transformar a cidade em paisagem, seja com ruas e avenidas interrompidas por praças, jardins e monumentos em seus horizontes, seja pela própria configuração das vias desenhadas como parques-lineares - os bulevares.

Enfim, um arcabouço de repertório variado, técnico-artístico, que proporcionou ao plano urbanístico de Santos uma forma ímpar, destacando Saturnino de Brito como um ícone no rol dos urbanistas brasileiros.

Seu envolvimento com a cidade santista, na verdade, iniciou-se em 1898, quando colaborou no planejamento de um sistema de separação absoluta para a rede sanitária (com uma rede para águas cloacais e outra para águas pluviais), incluindo estações elevatórias distritais. Proposta implementada apenas em 1905, ao assumir a Chefia da Comissão de Saneamento, a convite do novo governador do estado de São Paulo, Jorge Tibiriçá Piratininga (1955-1928).

O partido projetual de Saturnino de Brito foi realizar um plano geral para a cidade. Um plano que, diferentemente dos adotados até aquele momento - isolados e compartimentados -, englobasse os planos de saneamento, de melhoramentos e de expansão urbana, levando em consideração elementos já existentes, fossem eles naturais (como topografia e hidrografia) ou artificiais (como caminhos e pequenas estradas). 
A partir dos levantamentos feitos por planos anteriores, Saturnino de Brito tinha em mãos dados suficientes para elaborar um projeto extremamente detalhado. Desde o regime de chuvas, as variações das marés, os pequenos corpos fluviais que cortavam a planície, o acúmulo de águas provenientes das encostas, as curvas de nível, até estudos do solo, todos auxiliaram Brito na elaboração de uma CN modelo sob o ponto de vista ambiental.

Nesse sentido, o engenheiro-sanitarista tirou proveito dos canais abertos, implantados para drenar águas pluviais, servir como via de circulação para pequenas embarcações e constituir uma paisagem pitoresca no cenário urbano, uma vez que, às suas margens, desenharam-se vias com amplas calçadas - mais largas que três metros - e densamente arborizadas (ANDRADE, 1992). Canais de superfície eram naturalmente limpos por ação gravitacional, graças a um sistema de comportas que se abriam com a cheia das marés. A água do mar entrava por essas comportas, misturando-se com a água estanque até os pontos mais distantes da praia, sendo escoada, posteriormente, com a baixa-mar. Um método científico peculiar, aplicado na adaptação do meio natural às necessidades humanas.

Além disso, Saturnino de Brito instalou uma rede subterrânea para abastecer toda a nova cidade com água tratada, bem como uma rede coletora de esgoto, ligada diretamente aos equipamentos sanitários internos dos imóveis. Todo esse aparato infraestrutural foi executado entre 1905 e 1927, contando com 17 quilômetros de canais abertos e 80 quilômetros de rede subterrânea.

Simultaneamente, o parcelamento da expansão urbana foi traçado tendo por influência direta a Washington (1791) de Pierre Charles L’Enfant, como o próprio autor revelou (apud ANDRADE, 1991, p. 60). Distinta da proposta de Brant (1896), a malha reticulada obedeceu à geomorfologia da península, sendo rotacionada em momentos oportunos, apresentando quadras com dimensões variadas e sistema viário hierarquizado. A patte-d'oie foi utilizada para seccionar vias muito longas, criando espaços verdes para lazer e contemplação em seu ponto de coesão. Os lotes ganharam 
novo desenho em relação aos lotes coloniais, caracterizando-se por maior amplitude e recuos frontal e laterais, assegurados por uma legislação específica definida por Brito.

Um plano meticulosamente elaborado e implantado, que, segundo Carlos Roberto M. de Andrade (1991), deu “origem a uma nova cidade com um desenho extremamente moderno para a época, aproximando a paisagem urbana santista daquela das cidades europeias” (ANDRADE, 1991, p. 57).

É inegável, portanto, a importância desse exemplar para a urbanística brasileira. Porém, ele foi aqui inserido com outro propósito: servir como conexão à conceituação de CNs.

A propósito, julgo Santos como uma CN do século XX, apesar de sua fundação datar do século XVI. Uma CN empreendida pelo poder público e projetada por profissionais para atender a um determinado fim. Uma CN cuja área de expansão superou em muito a área da cidade existente, à semelhança dos projetos expansionistas para Nova York (1811), sob a responsabilidade de um comissariado público local; para Barcelona (1855), de Ildefons Cerdà; ${ }^{3}$ para Boa Vista (1944), ${ }^{4}$ do engenheiro civil Darcy Aleixo Derenusson; e para Paulínia (1969), do arquiteto Jorge Wilheim. Vilas ou cidades existentes que foram encapsuladas pela nova trama projetada; que cresceram repentina e ordenadamente; vilas e cidades que se tornaram CNs.

3 Barcelona de Cerdà era seis vezes o tamanho da cidade intramuros (CARRERAS, 1986).

4 Boa Vista, fundada em 1830, é considerada a terceira capital projetada no período republicano, após Belo Horizonte e Goiânia (TREVISAN; FICHER; MATTOS, 2017). Com o desmembramento, em 1943, do estado do Amazonas, originando o Território de Rio Branco (atualmente Roraima), o poder público local escolheu a cidade nortista como sua capital e designou o engenheiro civil Darcy Aleixo Ribeiro Derenusson (1916-2002) para elaborar um plano de urbanização. Este foi iniciado em 1944, sendo aprovado em 1946, e mobilizou uma vasta equipe dos mais conceituados especialistas em urbanismo e infraestrutura urbana. Do projeto, confeccionado numa planta em escala 1:1.000 e empreendido pela Riobras Industrial Ltda., destacam-se o novo centro cívico e suas 12 vias radiais extremamente largas, tendo a avenida principal cem metros de largura. 
Figura 4: Santos

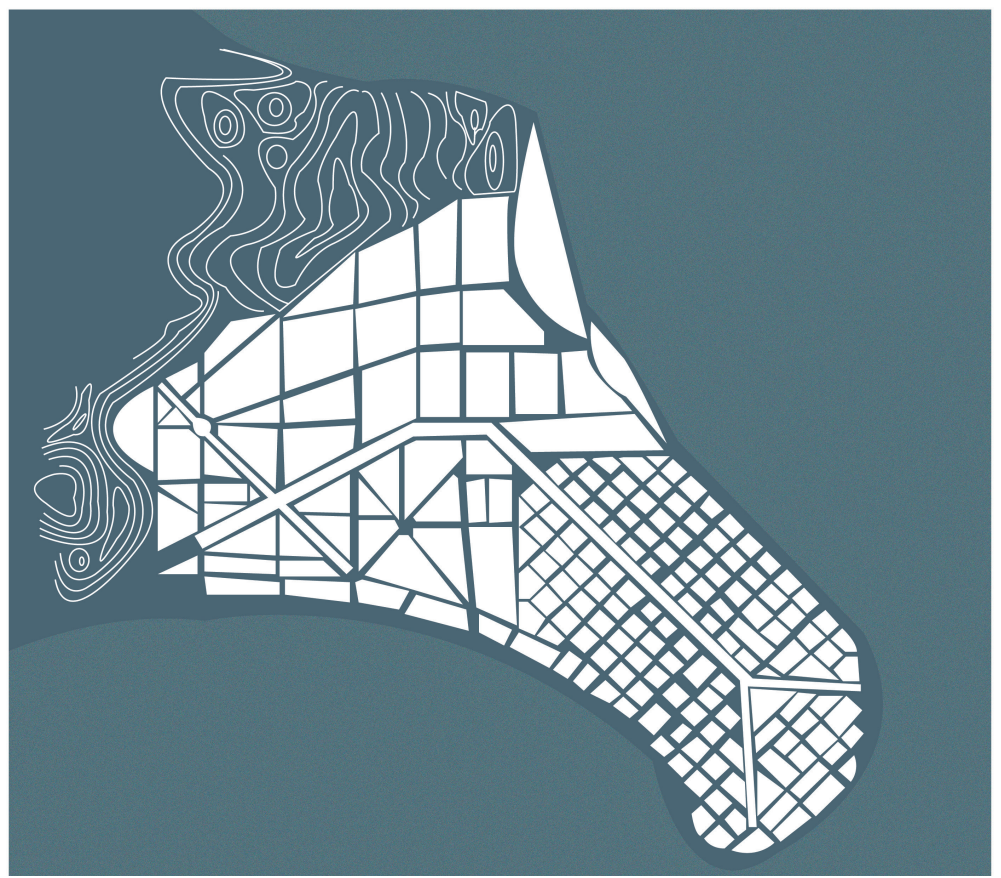

Essa concepção é compartilhada por pesquisadores poloneses, liderados pelo professor Bohdan Jalowiecki (diretor do EUROREG - Centro Europeu de Estudos Regionais e Locais da Universidade de Varsóvia), ao definirem uma CN de expansão como aquela que "foi construída segundo um plano de urbanismo preciso, com um tamanho previsto ao menos dez vezes superior ao núcleo existente” (HAUMONT, 1997a, p. 84, tradução nossa). ${ }^{5}$ Uma definição particular, formulada para auxiliar a identificação de CNs na Polônia.

Esses mesmos estudiosos se interrogaram: "um grande novo bairro, contando com 100 mil habitantes ou mais, construído ao lado de uma antiga cidade, [pode] ser definido como uma cidade nova?” (HAUMONT, 1997a, p. 84, tradução nossa). ${ }^{6}$

5 “[...] a été construit selon un plan d'urbanisme précis, avec une taille prédite au moins dix fois supérieure au noyau existant."

6 “[...] un grand nouveau quartier, avec 100.000 habitants ou plus, construit à côté d'une vieille ville, peut-on définir une nouvelle ville?" 
Indagação que nos remete ao projeto do bairro Cidade Nova de Manaus, idealizado pelo arquiteto e urbanista Ricardo Julião, em 1982, com 1.113 hectares de área e previsão inicial para 75 mil habitantes (REVISTA AU, 1987). Um bairro formado por dezenas de unidades de vizinhança, planejado para absorver o crescimento da capital manauara após a instalação de sua Zona Franca. Uma expansão urbana, sim, mas não uma CN como o nome fantasia nos faz acreditar que seja.

Diferente de Le Havre (França): uma cidade portuária fundada em 1517 que, após ser devastada, em 1944, por bombardeios de tropas aliadas na Segunda Guerra Mundial, foi reconstruída da tabula rasa a partir do projeto do arquiteto belga Auguste Perret (1874-1954), de 1945. Cidade colocada ao lado de outras três CNs - Tel Aviv (1925), de Patrick Geddes; Chandigarh (1952), de Le Corbusier; e Brasília (1957), de Lucio Costa e que, no colóquio "Brasília, Chandigarh, Le Havre, Tel Aviv - villes symboles du XX $X^{e}$ siècle” (set. 2007), foram anunciadas como personificadoras do urbanismo moderno.

Enfim, classificações de CNs, brevemente ilustradas - Santos, Nova York, Barcelona, Boa Vista, Paulínia, Le Havre, Tel Aviv -, que nos induzem a debruçar com maior dedicação sobre o tema. Um olhar à conceituação de CNs que pretendo realizar a partir de definições encontradas em fontes referenciais (livros, artigos, entrevistas etc.), agrupando-as por enfoques aproximativos. Um levantamento que utilizarei, posteriormente, para embasar uma definição funcional, ou seja, uma conceituação pessoal sobre aquilo que entendo por CNs e que permitirá balizar futuros trabalhos sobre esse tipo urbanístico.

\section{Definições empregadas}

Toda as cidades, é claro, já foram “novas”. (OSBORN; WHITTICK, 1977, p. 1, tradução nossa) ${ }^{7}$

7 “All towns, of course, were once 'new'.” 
É consenso: todas as cidades existentes já foram cidades novas em algum momento do passado, geradas a partir de circunstâncias - política, econômica, social e/ou cultural - específicas e implantadas sobre sítios de interesse.

Nesse sentido, o termo cidade nova configura-se como um atributo temporal relacionado ao período do surgimento, da fundação, dos primórdios históricos de uma determinada cidade, como atesta Melville Campbell Branch (1983). Atributo conceitualmente diferente ao trabalhado nesta obra: a cidade nova como um tipo urbanístico.

Para a geógrafa do Institut de Recherche pour le Développement (IRD-Paris), Márcia Regina de Andrade Mathieu, a CN enquanto um tipo do urbanismo pode ser reconhecida a partir do instante de sua criação, apresentando "um ponto de partida preciso, um ato de nascimento localizado no tempo e no espaço", sendo "um estabelecimento previsto com todos os atributos urbanos num espaço inicialmente virgem” (MATHIEU, 2008). Uma delimitação conceitual que ressalta outro ponto importante: o prever uma CN, ideia também trabalhada por Jean-Louis Huot:

Certas [cidades] nascem pelo crescimento sobre um elemento não urbano (castelo), outras pelo desenvolvimento espontâneo a partir de uma vila, outras, enfim, nascem pela vontade do homem num local onde não havia nada ou somente poucas habitações. Quando o plano da cidade é antecipadamente pensado e prevê a localização dos órgãos fundamentais, a aglomeração urbana é desenvolvida num quadro artificial seguindo um plano imposto pela vontade do homem. Esse tipo de aglomeração é frequentemente chamado de cidade criada. (HUOT, 1988, p. 8, tradução nossa). ${ }^{8}$

8 “Certaines naissent par croissance sur un élément non urbain (un château), d'autres par dévellopement spontané à partir d'um village, d'autres enfin par la volonté de l'homme à um endroit où il n'y avait rien, ou seulement quelques modestes habitations. Lorsque le plan de la ville 
Assim, entender CNs, para o autor francês, é ir além da data de sua fundação, é regressar para o período antecessor e verificar as circunstâncias e as ações a elas atreladas. Deslocamento esse que nos permite separar as cidades espontâneas das CNs, as quais foram, no momento anterior ao seu surgimento, concebidas, formuladas, idealizadas, intencionadas, inventadas, pensadas, planejadas, premeditadas, programadas, projetadas...

Designações utilizadas para qualificar uma aglomeração urbana criada ex nihilo (do nada), opondo-se ao desenvolvimento tradicional de uma cidade que, pouco a pouco, adquiriu seu status. Distinção feita, segundo o arquiteto Aldo Rossi, por inúmeros estudos urbanos, ao polarizar cidades planificadas e cidades não planejadas:

As primeiras são concebidas e fundadas como cidades, enquanto que as outras surgiram sem desenho consciente, como estabelecimentos que tiveram um desenvolvimento particular e assim puderam mostrar que elas possuem funções urbanas. O caráter urbano não aparece somente no curso de seu desenvolvimento, e sua estrutura é essencialmente o resultado da agregação de edifícios ao redor de alguns nós pré-urbanos. (ROSSI, 1981, p. 118, tradução nossa). ${ }^{9}$

Definição trabalhada muito antes pelo historiador do urbanismo Pierre Lavedan, em sua obra Géographie des villes:

a été arrêté d'avance em prévoyant l'emplacement des organes fondamentaux, l'agglomération urbaine s'est développée dans un cadre artificiel suivant un plan imposé par la volonté d'un homme. Ce type d'agglomération est souvent appelé ville créée."

9 "Les premières ont été conçues et fondées comme des villes, tandis que les secondes ont surgi sans dessin consciente, comme des établissements qui ont eu un développement particulier et ont ainsi montré qu'ils pouvaient remplir des fonctions urbaines. Le caractère urbain n'est apparru qu'au cours de leur développement, et leur structure est essentiellement le résultat de l'agrégation de bâtiments autour de certains nœuds pré-urbains." 
[...] uma cidade espontânea ou uma cidade querida, o traço de seu plano, os desenhos de suas ruas visivelmente, não se devem ao acaso. Há uma obediência às regras, inconscientemente no primeiro caso, conscientemente e abertamente no segundo. Há sempre um elemento gerador do plano. (LAVEDAN, 1936, p. 55, tradução nossa)..$^{10}$

Nesse sentido, as CNs expõem, sem disfarces, seu processo de formação, revelando a todos os componentes que contribuíram para sua criação e sua materialização. Assumem, com isso, a imagem de cidades pré-concebidas, fato ocorrido na construção da introduced capital de Botswana: Gaborone (1963), que se opõe a outras capitais, como Paris e Londres, ao apreendermos premeditações em sua concepção e implantação (BEST; YOUNG, 1972).

A ideia de CNs induz a uma noção de programação, característica da planificação (BOYER, 1983). Necessita de uma mobilização conjunta de capacidade técnica, material, financeira e institucional do Estado, da coletividade e dos movimentos sociais (BOUMAZA et al., 2006); ou é induzida por um gesto autoritário de um Estado intervencionista ou da tentativa do meio profissional de criar os limites do saber do momento (QUERRIEN; LASSAVE, 2005). Essa ideia surgiu, segundo a arquiteta Maria Elisa Costa, ${ }^{11}$ a partir de:

10 “[...] une ville spontanée ou d'une ville créée, il est certain que le trace de son plan, les dessins de ses rues notamment, n'est pas dû au hasard. Il y a une obéissance aux règles, inconsciemment dans le premier cas, consciemment et ouvertement dans le second. Il y a toujours un élément générateur du plan."

${ }^{11}$ Os arquitetos Maria Elisa Costa e Eduardo Sobral, sob a consultoria de Lucio Costa, projetaram a CN de São Bento da Lagoa em 1975 (não construída). Idealizada para ser implantada no litoral fluminense, próximo a Maricá, a cidade serviria como núcleo balneário para veranistas de fins de semana. Aos moldes de Brasília, seu sistema viário foi trabalhado separando vias de veículos e pedestres, com superquadras sem esquinas ocupadas por torres multifuncionais de 2 pavimentos, barras residenciais semicirculares ou unidades habitacionais isoladas. A área central agregaria todas as funções necessárias para autonomia da cidade, enquanto as margens da lagoa de Maricá e a orla marítima abrigariam a escala bucólica mediante um projeto paisagístico próprio (REVISTA MÓDULO, 1975). 
[...] dois tipos de circunstâncias: a tomada de posse de territórios novos - como as cidades fundadas na colonização do Brasil e Brasília - ou a intenção de organizar uma ocupação regional existente, introduzindo novos núcleos - por exemplo, as new towns inglesas. No primeiro caso, como Lucio Costa diz bem, na Memória Descritiva do Plano Piloto de Brasília, a cidade não é decorrência de um plano regional, mas a causa dele; e, no segundo, a cidade surge a partir de um desenvolvimento regional pré-existente. (COSTA, 2007, entrevista)

Definições pontuais que irão se somar a outras encontradas, selecionadas e aqui apresentadas. Definições direcionadas a qualificar um objeto que se metamorfoseou, assumindo várias facetas ao longo da história.

\section{Cidades novas no tempo}

Kahun, no Egito do século XIX a.C., tida como o primeiro exemplar de cidade planejada em estrutura de grelha no Ocidente. As cidades de dominação grega de Mileto, nas costas da Anatólia (atualmente, Turquia) do século V a.C., ou de Túrios e Pireu, na Grécia do século I a.C. As cidades do Império Romano, como Cosa, implantada estrategicamente ao norte de Roma no século III a.C., e Timgad, no norte africano do século I d.C., como parte do domínio romano sobre aquele continente. As póvoas, ${ }^{12}$ as bastides (vilas militares) e as villes d'évêque (vilas religiosas), na Europa medieval. A asteca Teotihuacán, no México do período pré-colombiano. A Cidade Proibida, na Pequim do século XV. As Leis das Índias que nortearam os projetos das cidades novas da América espanhola. As cidades empresariais europeias, com o advento da indústria a partir do século XVIII. Las Vegas, nos Estados Unidos da América de 1905, e as demais CNs criadas em função do turismo no século XX. As new towns inglesas ou as

${ }^{12}$ Núcleos fundados ou reformados pela prática de arruamento como elemento estruturador do espaço urbano. 
villes nouvelles francesas do pós-Segunda Guerra Mundial. Kiruna, na Suécia, de 1900 e de 2030, uma CN por duas vezes. ${ }^{13}$ Esses são alguns exemplos de que a existência de CNs, há muito, faz parte da história do urbanismo.

Mesmo no Brasil, o caso de CNs antecede os exemplares do período imperial e republicano, como revelam alguns estudos. ${ }^{14}$ Curiosamente, antes mesmo da chegada dos portugueses em solo brasileiro, os nativos indígenas criavam assentamentos com intencional organização espacial. Exemplos disso eram as tribos bororos do Centro-Oeste (SÁ, 1983), cuja distribuição de atividades no espaço derivava de aspectos sociais (clãs), bem como o povo tupi, que cercava sua taba por paliçadas de troncos finos e organizava suas moradas ao redor de um terreiro quadrado, padrão que foi utilizado nas feitorias e vilas no século XVI (AZEVEDO, 1956). A partir daí, as cidades administrativas implantadas na costa - determinadas pelas “Cartas Régias” (MARX, 1980) -, os vilarejos jesuíticos e os assentamentos missionários - extremamente regulares e organizados conforme a ordem religiosa (carmelitas, franciscanos etc.) -, as vilas pombalinas - implantadas na hinterlândia brasileira - e mesmo quilombos construídos por escravos fugitivos representam a trajetória e a diversidade de núcleos regulares em território nacional, desde meros assentamentos incipientes a verdadeiras CNs.

${ }^{13}$ A cidade de Kiruna, Suécia, foi fundada em 1900 por Hjalmar Lundbohm. Uma cidade-modelo, projetada por arquitetos, para abrigar operários que trabalhavam na mina de ferro local. O projeto urbano foi realizado para proteger seus moradores do clima frio (próximo ao círculo polar), com as vias dispostas de modo a resguardar os pedestres dos ventos invernais. Com o passar dos anos, e devido à exploração do minério, o solo urbano começou a ceder e a colocar a cidade em risco de desabamento. Pensando nisso, o Conselho Municipal aprovou a construção da nova prefeitura a cinco quilômetros de seu local original, em zona protegida. A população de 20 mil habitantes será transferida num período de até 25 anos. A empresa mineral Luosavaara-Kiirunavaara (LKAB) vai arcar com a maior parte dos custos de deslocamento da cidade. Ainda espera recriar uma nova cidade-modelo para a Suécia, a nova Kiruna. Trata-se de um caso de uma CN empresarial que se tornará uma CN de realocação (NIHLÉN, 2007).

${ }^{14}$ Como os trabalhos seminais: Vilas e cidades do Brasil colonial: ensaio de geografia urbana retrospectiva, de Aroldo de Azevedo (1956); Subsídios para o estudo da influência da legislação na ordenação e na arquitetura das cidades brasileiras, de Francisco de Paula Dias de Andrade (1966); Evolução urbana no Brasil (1500/1720), de Nestor Goulart Reis Filho (1968); e Novas vilas para o Brasil-Colônia: Planejamento espacial e social no século XVIII, de Roberta Marx Delson (1979). 
Esse breve panorama histórico, mundial e brasileiro sobre CNs revela a origem remota de tal tipo e sua difusão abrangente. Um cenário comprovado na obra Bibliographie sur les villes nouvelles françaises, de Pierre Merlin e Mireille Gely (1989), cuja ampla pesquisa sobre estudos de CNs - não apenas francesas - exibe, dentre os inúmeros temas abordados, bibliografias sobre suas origens (anteriores à Revolução Industrial e às utopias urbanas do século XIX) e sobre as ocorrências no exterior (na Europa Ocidental e Oriental, nos EUA, no Oriente Médio, na Ásia, na Oceania, na África, na América Latina e no Brasil).

É uma fonte referencial e, simultaneamente, um atlas de CNs no mundo, similar aos trabalhos realizados por Pierre Merlin em Les villes nouvelles (1969a); por Claude Chaline em Les villes nouvelles dans le monde (1985); e por Frederic Osborn e Arnold Whittick em New towns: their origins, achievements and progress (1977), que, ao finalizarem seu livro, anexaram um quadro com centenas de CNs criadas a partir de 1900: uma tabela organizada por países e respectivos exemplares - por exemplo, no Brasil, citam-se apenas: Brasília, Cidades dos Motores e Volta Redonda -, contendo: informações gerais, datas de designação, população prevista e atual, além de menções sobre a existência de outros casos não relatados, como a ex-União Soviética, onde os autores creditam a presença de 1.000 a 2.000 CNs.

São obras que se contrapõem a relatos e estudos restritivos, que situam a execução desse tipo urbanístico a uma única região, como fez Vincent Fouchier (secretário geral do Programme interministériel d'histoire et d'évaluation des villes nouvelles), ao considerar as CNs como "um fenômeno, sobretudo, do norte-europeu” (apud DIEBOLD; LEMONIER, 2001, p. 10, tradução nossa). ${ }^{15}$ Ou ainda dezenas de pesquisas que enquadram CNs como um produto da teoria de Ebenezer Howard e suas cidades-jardins (1898). Curiosamente, em busca nos arquivos estrangeiros pela temática CNs, os resultados obtidos quase sempre conectavam o termo a programas de cidades-satélites criadas ao redor de uma grande metrópole

15 “[...] un phénomène principalement de l'Europe du Nord.” 
após a Segunda Guerra Mundial, fosse na Europa, na Ásia, nas Américas, na África ou na Oceania, tendo a teoria Cidade-jardim como influência direta.

O termo cidades novas (tradução de new towns), associado à teoria howardiana de cidade-jardim, imputa um caráter específico ao nosso objeto de interesse: o de controlar a expansão das grandes cidades pela criação de novos núcleos.

A origem do ideário cidade-jardim remete à publicação do livro To-morrow: a peaceful path to real reform (Para o-amanhã: um caminho tranquilo para a reforma autêntica) no ano de 1898, de autoria de Ebenezer Howard. Reeditado em 1902, com o título Garden cities of tomorrow (Cidades-jardins de amanhã), esse documento tornou-se paradigmático para o urbanismo moderno ao apresentar um novo tipo urbano - uma cidade diferenciada em seus aspectos físicos e em sua organização econômica, política e social. Ainda apresenta uma discussão sobre o futuro das cidades. A expansão da cidade idealizada pelo taquígrafo inglês dar-se-ia pela construção de outras representadas em diagramas. Os esquemas mostram uma rede de sete cidades interligadas pela ferrovia, sendo seis cidades menores periféricas - com 32 mil habitantes - e uma central chamada de Cidade Social - com 58 mil habitantes. Essa cidade centralizaria um número de atividades maior do que as demais (CREESE, 1992) - um protótipo de várias versões.

As CNs, nesse caso, surgem como um tipo de planejamento urbano e territorial de desindustrialização e de desurbanização das grandes cidades congestionadas, como aponta Guy Baudelle (2004). Uma vez implantadas, absorveriam uma parte significativa do crescimento demográfico urbano e criariam zonas de atividades econômicas ao redor de uma cidade vultosa. Nesse sentido, as CNs no século XX adquirem uma função que irá, às vezes, restringir sua definição a um mecanismo de expansão urbana organizada.

São inúmeros os autores que associam CNs às cidades criadas para controlar o crescimento de outras existentes. A iniciar por René Allart (s.d., p. 12, tradução nossa) ${ }^{16}$ e sua comparação entre os tipos inglês e francês:

16 “Il faut équiper des terrains neufs, les transformer en "tissu urbain”. La démarche qui a consisté à présenter en face de l'urbanisation périphérique, moyen classique d'extension des villes, la 
É preciso equipar os terrenos novos, transformá-los em tecido urbano. A demanda necessária apresentou, em face à urbanização periférica - meio clássico de extensão das cidades -, a possibilidade de se criar cidades novas, nascidas de uma dupla reflexão: uma constatação do colapso de formas clássicas de urbanização francesa [o crescimento radioconcêntrico] e uma reflexão crítica sobre aquilo que chamamos de sucesso das cidades novas inglesas.

E a análise de Sabine Fachard (1982, p. 38, tradução nossa) ${ }^{17}$ sobre as villes nouvelles da grande Paris:

As grandes linhas do "projeto villes nouvelles" são conhecidas: trata-se de distanciar as contradições da cidade, pesquisa do equilíbrio moradia-emprego, comodidades da cidade sem os problemas da cidade tradicional, com bons serviços interior e exterior, equipamentos e comércios, ruas, praças, vastos corredores verdes, parques urbanos, bases de lazer, etc.

Incluindo ainda a classificação dos dois tipos, feita por Françoise Choay e Pierre Merlin (2005), conforme a conexão entre CNs e a cidade principal: o tipo inglês (new towns), com CNs situadas nos arredores de uma metrópole, sem continuidade, com a preocupação de descongestionar e de estruturar a região urbana em uma escala mais vasta que aquela da aglomeração de base; e o tipo francês (villes nouvelles), com CNs situadas em continuidade espacial com grandes aglomerações,

possibilite de créer des villes nouvelles, est née d'une double réflexion: um constat d'échec des formes classique de l'urbanisation em France e une réflexion critique sur ce que l'on appelle le succès des villes nouvelles anglaise."

17 "Les grandes lignes du "projet ville nouvelle" sont connues : il s'agit du fait de dépasser les contradictions de la ville, recherche d'équilibre habitat-emploi, commodités de la ville dégagée des contraintes de la ville traditionnelle, à savoir bonnes dessertes intérieures et extérieures, équipements et commerces, rues, places, mais aussi vastes coulées végétales, parcs urbains, bases de loisirs, etc.” 
destinadas a orientar e estruturar o desenvolvimento das periferias, sem sinal de independência entre elas e a cidade-mãe.

Enfim, CNs que surgem como solução ao espraiamento urbano desordenado, difundidas, principalmente, no período de reconstrução europeia no pós-Segunda Guerra Mundial, como na Grã-Bretanha e seu New Town Act de 1946, cuja autoria é dada ao urbanista Patrick Abercrombie (1879-1957).

Tratava-se de um plano - embasado, por exemplo, na obra The building of satellite towns (A construção de cidades-satélites), de Charles Benjamim Purdon (1925) -, que previa a necessidade de descentralização das grandes cidades britânicas e propunha uma reforma da legislação urbanística existente. Uma proposta de renovação urbana que acarretou na geração de dezenas de new towns por todo o território inglês, independentes econômica e administrativamente dos centros urbanos existentes (CLAPSON, 1998).

Em oposição às new towns inglesas - distantes e carentes de ligação com Londres (BEHAR; ESTEBE; GONARD, 2002) -, as villes nouvelles francesas, para Vito Ahtik (1969, p. 385, tradução nossa), ${ }^{18}$

[...] se apresentam num contexto de reestruturação da área metropolitana. O conjunto do projeto de planejamento se articula entre a reconstrução do centro tradicional da metrópole e a criação de alguns nós na armadura urbana. Cada cidade nova terá uma vocação privilegiada (setor terciário ou quaternário). Enfim, a cidade nova

18 “[...] s'inscrit d'emblée dans le contexte de la restructuration de l'aire métropolitaine. L'ensemble du projet d'aménagement s'articule donc entre la reconstruction du centre traditionnel de la métropole et la création de quelques nœuds de l'armature urbaine. Les différents activités doivent s'ordonner au sein de cet ensemble. Chacune des villes nouvelles aurai donc une vocation privilégiée (dans la plupart des cas, un fort accent est mis sur le secteur tertiaire ou quaternaire). Enfin, la ville nouvelle s'isole de la métropole (soit géographiquement, soit par une ceinture verte, un lac ou du fait de la clôture du site), mais en même temps elle se situe sur un des principaux axes de communication de la région. En termes de nos catégories d'analyse, la ville nouvelle française ne se veut ni satellite, ni autonome, mais une ville secondaire; ni complètement différenciée, ni spécialisée, mais à vocation privilégiée ; ni concentrée, ni diffuse, mais un pôle intégré à l'ensemble de l'aire métropolitaine." 
francesa se isola da metrópole (seja geograficamente, seja por um cinturão verde, um lago, ou por condições de topografia), mas, ao mesmo tempo, ela se situa sobre um dos principais eixos de comunicação da região. Em termos de categoria de análise, a cidade nova francesa não é nem satélite, nem autônoma, mas uma cidade secundária; nem completamente diferenciada, nem especializada, mas de vocação privilegiada; nem concentrada, nem difusa, mas um polo integrado ao conjunto da área metropolitana.

As villes nouvelles foram CNs empreitadas durante a presidência do general Charles de Gaulle (1890-1970), entre 1958 e 1969, sob o comando do delegado geral Paul Delouvrier (1914-1995). São núcleos que não deveriam se assemelhar às CNs inglesas, mas incorporar o sentido de "centros urbanos novos", de "cidades antiperiferia”, como desejado por Delouvrier e sua equipe. De centros urbanos novos a villes nouvelles, o uso do termo CNs em francês se consolidou apenas anos mais tarde, conforme o próprio Delouvrier, em 1966, explicou (MURARD; FOURQUET, 2004). A escolha do termo ville nouvelle, em detrimento de centre urbain nouveau, foi uma questão semântica. Ao pronunciar os novos projetos ao Ministério de Finanças ou mesmo à população, mediante a segunda expressão, nenhum resultado surtiria, ao passo que o primeiro termo teria uma chance de ser aceito (assimilado como algo novo, que receberia novos equipamentos para estas regiões periféricas à capital francesa); algo distante de uma renovação e sim próximo ao senso de colocar a aglomeração parisiense no século XX. Estando situadas na região parisiense, sendo na verdade uma forma moderna de periferia - diferente aos criticados conjuntos habitacionais periféricos: as HBMs (Habitation à Bon Marché) -, essas villes nouvelles poderiam receber equipamentos que o centro de Paris não mais comporta por falta de espaço: museus ultramodernos, teatros e desenvolvimentos artísticos novos. O delegado geral ainda apontou que: 
Em vez de abrir uma sequência de loteamentos, nós pensamos em levar serviços, universidades, grandes estabelecimentos, órgãos públicos regionais, áreas de esporte para o centro das periferias novas que não serão mais periferia, mas lugares denominados de villes nouvelles. Mas estas villes nouvelles sejam a forma moderna de crescimento de Paris e não mais cidades antiperiferia que pudessem ser colocadas em qualquer parte do território. Aí está, para mim, a escolha decisiva. (DELOUVRIER apud MURARD; FOURQUET, 2004, p. 128, tradução nossa). ${ }^{19}$

Portanto, ao requalificar o modo de fazer e nomear a periferia da grande cidade, as villes nouvelles francesas geram um novo significado do termo CNs e surgem como reinterpretação do tipo inglês.

Sejam inglesas ou francesas, independentes ou dependentes, isoladas ou continuações de cidades-mães, esse tipo de CNs foi adotado em inúmeros países no entorno de capitais, como Helsinque, Estocolmo, Copenhague, Amsterdã, Seul, Argel, Cairo, Caracas e Brasília.

Tipo que, por vezes, ganha novos nomes, como as twin towns e as new towns in-town. As cidades gêmeas, discípulas dos exemplares britânicos e israelenses de CNs, aparecem como um plano estratégico para a construção de novas cidades na Palestina, visando a suprir necessidades de moradia e oferecer empregos. Localizadas próximas a uma cidade existente, reforçando seu processo de urbanização, as twin towns foram programadas em duas etapas: primeiramente, implantação na periferia de metrópoles e, posteriormente, ao redor de cidades menores, promovendo seu crescimento (KHAMAISI, 1998).

19 “Au lieu de faire une file de lotissements, nous avons pensé qu’il fallait amener les services, universités, grands établissements, préfectures, terrains des sport au cœur des banlieues nouvelles qui ne seront plus des banlieues et qui ainsi prennent le nom de villes nouvelles. Mais ces villes nouvelles sont la forme moderne de la croissance de Paris et non pas des villes complètement autonomes que l'on aurait pu placer n'importe où. Voilà ce que nous avons voulu faire." 
Já as CNs-na-cidade aparecem pela primeira vez em 1966, como título do artigo escrito pelo norte-americano Harvey S. Perloff, publicado no Journal of the American Institute of Planners. Perloff sugeriu, no início dos anos 1950, uma estratégia para desenvolver uma área ao redor da Universidade de Chicago e, em 1966, ele fez a mesma proposta como base para um programa nacional. Ele via o conceito de new towns in-town como uma revitalização de grandes áreas urbanas pelo aproveitamento do ambiente já existente e pela qualidade de vida de seus moradores, incorporando um simples programa (uma variedade de atividades para assistência aos habitantes e componentes de desenvolvimento urbano). Tal conceito foi traduzido por Pierre Merlin e Michel Sudarskis (1991) como operações de renovação e de regeneração urbanas; ou como novas zonas industriais em áreas urbanas, tornando-se polos de desenvolvimento empreendidos por políticas públicas (D’ARC; SCHNEIER, 1983).

Também foi um conceito que embasou o American Model Cities Programme (Programa Americano de Cidades-Modelo), proposto em fins dos anos 1960, nos Estados Unidos da América. O programa, instituído no governo do presidente Lyndon Baines Johnson (1908-1973), pretendia construir pequenas, novas e dinâmicas comunidades em terras federais inseridas em algumas cidades norte-americanas. Buscava-se levar melhorias físicas e sociais a complexos urbanos carentes por meio de planejamento, readequação do traçado, transporte, equipamentos de saúde, educação e segurança. Essas cidades-modelo foram iniciadas, mas nenhuma foi efetivamente concluída (PHILLIPS; YEH, 1987).

De Kahun às new towns in-town, das vilas e mochas do período colonial brasileiro às CNs derivadas da teoria howardiana, passando pelas peculiaridades que distinguem new towns e villes nouvelles, temos um apanhado histórico que nos permite ter uma maior compreensão sobre o universo das CNs, bem como verificar seus desdobramentos funcionais e suas aplicações em contextos diversos - verdadeiro campo de experimentações, como alguns autores preferem defini-las. 
Cidades novas como laboratórios socioespaciais

Criar uma cidade [...] é sempre criar uma cultura, quer dizer os modelos individuais e comuns de atitudes. Augustyn Bańka, Structure psychologique de la planification du milieu, 1985 (apud HAUMONT, 1997a, v. 2, p. 153, tradução nossa). ${ }^{20}$

Além de definições aplicadas segundo o momento histórico, as CNs foram também definidas como experimentações sociais e físicas na busca por uma melhor qualidade de vida e como delineamento traçado por estudiosos e pesquisadores preocupados em caracterizar as CNs como laboratórios, com os mais variados tipos de ensaios.

A maior parte das propostas de cidades idealizadas surgiu como uma crítica à cidade contemporânea e pelo desejo de se criar a condição de reequilíbrio social, educando seus habitantes mediante sua organização e sua arquitetura, dando-lhes a condição necessária para o seu desenvolvimento socioeconômico. Trata-se de um tipo de cidade unitariamente projetada, a absoluta presteza do idealizador e do construtor de poder prever as necessidades físicas, psíquicas dos habitantes e de traduzi-las em formas arquitetônicas (BERTUGLIA; TICH; STANGHELLINI, 2004). Concretizações de uma ideia, dentre as quais muitas foram destinadas a serem cidades-modelo, tendo em comum uma ideia de partida, que não são somente alojamento e infraestrutura, mas sim uma manifestação física de certa ideia de vida urbana; manifestos políticos daquilo entendido como vida urbana para seus habitantes (SAFIER, 1977).

Do ideal ao real, as CNs foram constantemente alimentadas pela busca de condições melhores, mediante “ações inovadoras e experimentais” (MONTAGU; SOKOLSKY, 1995, s/p, tradução nossa), ${ }^{21}$ como aquelas implementadas na primeira cidade-jardim: Letchworth (1903), na Inglaterra, e na colônia agrícola de

\footnotetext{
20 “Créer une ville [...] c'est toujours créer une culture, c'est-à-dire des modèles d'attitude individuels et communs." "

21 “[...] actions innovantes et expérimentales [...]"
} 
Ceres (1941), no estado de Goiás, Brasil. Duas cidades mais distantes do que geograficamente, porém unidas por princípios sociais estipulados por seus criadores.

Em Letchworth, projetada pelos arquitetos Raymond Unwin (1863-1940) e Richard Barry Parker (1867-1947), sob o olhar atento de Ebenezer Howard, todo o plano da $\mathrm{CN}$, assim como seu tranquilo funcionamento, foi pautado em regulamentos estabelecidos pela First Garden City Ltd. e, posteriormente, pelos primeiros moradores. Criaram-se normas e regras para o uso do solo e controle do conjunto paisagístico, proibiu-se a abertura de casas comerciais na área residencial, a implantação de indústrias poluidoras, a abertura de lojas de bebidas alcoólicas ${ }^{22}$ e até o toque de sirenes nas fábricas ou sinos em igrejas e escolas. Também enunciaram o tipo de construções, o número limitado de artesãos por bairro para garantir clientela e o controle sobre a criação de animais domésticos para que não perturbassem os vizinhos (HALL, 1995; HOWARD, 1996).

Já Ceres, considerada uma colônia agrícola modelo e uma das maiores produtoras de cereais do estado de Goiás nos anos 1940 e 1950, foi projetada pelo agrônomo carioca Bernardo Sayão Carvalho Araújo (1901-1959), responsável também pelas rígidas normas de posturas e condutas sociais da CN. Bernardo Sayão "não admitia bebidas, prostituição e jogo na área da colônia” (MARQUES, 2009, p. 1), acarretando, na criação de outro assentamento vizinho, Rialma, na margem oposta do Rio das Almas, a permissividade de quase tudo o que era proibido na colônia!

Letchworth e Ceres são, portanto, classificadas como CNs não somente pelas circunstâncias envolvidas, mas também pelos aspectos sociais determinados por seus criadores a partir da cultura em voga.

Nesse sentido, as CNs como campo de experimentação social foram analisadas por Sabine Fachard (1982), que as diferenciou da cidade tradicional durante seu

\footnotetext{
${ }^{22}$ Em sua obra teórica sobre as cidades-jardins, Ebenezer Howard dedicou um capítulo exclusivo ao tema da venda de bebidas (capítulo VII), um problema que as cidades inglesas apresentavam. O alto índice de alcoolismo, principalmente na massa operária - um possível escape da realidade caótica urbana e das condições imorais de trabalho -, levou o autor a proibir a venda de bebidas em sua cidade idealizada.
} 
estágio inicial, em que o modo de vida é mais intenso e mais diversificado. Para a autora, após estudos das villes nouvelles francesas dos anos 1960,

[...] as cidades novas vieram substituir um sistema complexo de organização espacial e funcional voluntário, onde cada questão colocada exige uma resposta e meios compatíveis com a coerência do conjunto. [...] A margem de liberdade que oferecem as cidades novas é uma especificidade que muito lhes convém, mas que tem por corolário a necessidade de fazer escolhas: decidir aquilo que é bom ou ruim. (FACHARD, 1982, p. 38, tradução nossa). ${ }^{23}$

Esse é um processo de vida que permite aos futuros habitantes da CN uma mudança, como colocou Anatole Kopp em seu livro Changer la vie, changer la ville (1975). Para mudar a vida, haveria a necessidade de mudar a cidade, ou melhor, de cidade. Era a oportunidade para os mais jovens conseguirem empregos promissores, adquirir sua moradia, garantir qualidade de vida para seus filhos etc. Um novo modo de vida, ideal para casais jovens com crianças (DUCON; YOKOHARI, 2006), como verificado na cidade-satélite de Águas Claras, Brasília.

A mais nova das cidades-satélites do Distrito Federal brasileiro, concebida nos anos 1980 pelo arquiteto Paulo Zimbres (1933-2019), atrai um perfil de habitantes único e diferenciado das demais. Segundo último censo registrado (2010), jovens casais com filhos entre 0 e 6 anos, de classe média, trabalhadores no Plano Piloto, escolheram a cidade-satélite de Águas Claras como sua morada na capital federal. A cidade prevista como resposta ao urbanismo modernista segregador existente no Plano Piloto de Lucio Costa (1902-1998) e nas cidades-satélites mais antigas infe-

23 “[...] les villes nouvelles sont venues substituer un système complexe d'organisation spatiale et fonctionnelle volontaire où chaque question posée exige une réponse et des moyens compatibles avec la cohérence de l'ensemble. [...] La marge de liberté qu'offrent les villes nouvelles est une spécificité que beaucoup leur envient mais qui a pour corollaire la necessite de faire des choix: en clair, décider de ce qui est 'bien' et de ce qui est 'mal'."' 
lizmente se transformou, com o aval estatal e o domínio das construtoras privadas, em uma cidade com características típicas das áreas de expansão urbana no Brasil: torres habitacionais com mais de 20 pavimentos; espaços públicos desqualificados - praças abandonadas, muros contínuos, calçadas intransitáveis, centralidade não definida etc. -; áreas de lazer privatizadas em espaços condominiais; ruas estreitas para um fluxo intenso de veículos etc. Talvez por esse cenário familiar - aliado a uma resistência em habitar as superquadras de Lucio Costa - ou pela oferta imobiliária, muitas famílias vindas dos diferentes recantos do país tenham optado por Águas Claras como a cidade para o começo de uma nova vida.

Seja por condições pré-estabelecidas, seja por condições convidativas a um público específico, as CNs propiciam um novo gênero de vida, em que a posição das grandes funções urbanas - moradia, emprego, transporte etc. - leva em conta os novos modos de posicionamento individual e coletivo (VERMEERSCH, 2005). No Japão, por exemplo, a CN de Tsukuda surgiu como solução a um dos males da vida contemporânea. Fundada em 2000, a nordeste de Tóquio, esse assentamento nasceu com um novo conceito para os padrões de vida urbana: a slow life (vida pacata), contrapondo-se ao estresse e à agitação das grandes metrópoles. Um estilo de viver específico, que leva autores como Bertrand Warnier (1988) a taxar as CNs como apenas um problema de planejamento do quadro de vida ou um parto de planificação urbana, e não um pacto urbanístico.

Mas se, para alguns pesquisadores, as CNs se tornaram lócus para composições sociais particulares - espaço para controle ou libertação de seus futuros habitantes -, para outros estudiosos elas também se caracterizaram como verdadeiros laboratórios urbanístico e arquitetônico.

Ao suscitar indagações como: a cidade nova apresenta uma concepção e um método particular de urbanismo? Havia uma arquitetura específica? Como ocorreu sua inserção no meio escolhido para sua implantação? As cidades novas eram um laboratório sobre o plano de qualidade arquitetônica, urbanística e ambiental? Pierre Merlin e Michel Sudarskis (1991) nos atentam para a temática como um 
vasto arcabouço de experiências projetuais; como uma temática de linguagem própria (VADELORGE, 2005); ou, ainda, como “um momento de criação privilegiado [...], um tipo de laboratório ideal” (POITEVIN; ETTEINGER; ANTIER, 1993, p. 189, tradução nossa). ${ }^{24}$ Isso pode ser verificado na proposição de pequenas cidades-estado a serem criadas nos oceanos, uma ideia patrocinada pelo bilionário norte-americano Peter Thiel e comandada pelo Seasteading Institute. Tratam-se de plataformas flutuantes ancoradas em águas internacionais, sem relação com qualquer país e, portanto, independentes politicamente: verdadeiras CNs flutuantes. Ou seja, experiência urbanística e arquitetônica que aproxima as CNs dos conceitos de inovação ou cidade-objeto. Para Gilbert Smadja (1987, p. I, tradução nossa), ${ }^{25}$ a “inovação é consubstancial às cidades novas. Já no início, o projeto e sua implantação estão situados num contexto de abertura à inovação”. Cada CN é uma cidade-objeto, sendo uma projeção no futuro a partir de lições da história e dos contratempos do tempo presente (BOUMAZA et al., 2006).

Inovadoras e objetos idealizados, tais CNs propiciam um estudo minucioso, servindo de referência histórica, como salienta Aymeric Zublena:

Se um historiador de arquitetura urbana desejasse estudar a evolução das concepções arquitetônicas entre os anos 1960 e 1980, é nos centros urbanos das cidades novas que ele encontraria o mais rico terreno de análise. (apud FRANCE, 2007, p. 80, tradução nossa). ${ }^{26}$

24 “[...] un moment de création privilégié [...], un type de laboratoire idéal. »

25 “[...] innovation est consubstantielle à villes nouvelles. A l'origine, le projet et sa mise en ouvre s'inscrivent dans un contexte d'ouverture à l'innovation [...].”

26 "Si un historien de l'architecture urbaine voulait étudier l'évolution des conceptions architecturales au cours des annés 1960 à 1980, c'est dans les centres urbaines des villes nouvelles qu'il trouverait le plus riche terrain d'analyse." 
Essa é uma afirmativa similar às colocações de Alain Coulon, ao situar as CNs como a materialização temporal de uma arquitetura e de um urbanismo recorrentes numa época:

[...] as cidades novas estão inscritas numa produção espaço-temporal como testemunhas físicas da evolução das práticas num período de transformações radicais, e que as contradições formais inerentes ao sistema de produção (divisão de espaços e justaposição das tecno-práticas) constituem a infraestrutura visível de uma imagem física da cidade moderna. (COULON, 1993, p. 90, tradução nossa). ${ }^{27}$

e de Vincent Fouchier, ao qualificar as villes nouvelles francesas:

As cidades novas foram um terreno privilegiado para as tentativas de experimentações arquitetônicas, onde podemos observar in loco a evolução em curso dos seus 40 anos. (apud DIEBOLD; LEMONIER, 2001, p. 13, tradução nossa). ${ }^{28}$

Já Françoise Choay e Pierre Merlin, embora compartilhem da ideia de CNs como laboratórios, fazem uma distinção entre o urbanismo e a arquitetura presentes nas cidades do tipo satélite (CNs de expansão urbana):

\footnotetext{
27 “[...] ces villes nouvelles ont inscrit, dans leur production spatio-temporelle le témoignage physique de l'évolution des pratiques dans um période de leur transformation radicale, et que les contradictions formelles inhérentes au système de production (division des espaces et juxtaposition des techno-pratiques) constituent l'infrastructure visible d'une image physique de la ville moderne."

28 "Les nouvelles villes étaient un terrain privilégié pour les tentatives d'expérimentation architecturale, où l'on peut observer l'évolution continue de ses 40 ans."
} 
Se as CNs foram, frequentemente, em seus países (ex-URSS, Grã-Bretanha, França, Holanda, Suécia, Finlândia), laboratórios em matéria de urbanismo, oferecendo um meio de vida melhor que as periferias ordinárias, elas não se constituíram, no entanto, sobre o plano da arquitetura (à exceção de algumas realizações isoladas como Tapiola, na Finlândia), um conjunto de inovação esperada. (CHOAY; MERLIN, 2005, p. 946, tradução nossa). ${ }^{29}$

Seja qual for a leitura empregada, tais "laboratórios in vivo" do urbanismo e da arquitetura podem ser, atualmente, visitados, estudados, analisados e criticados, a exemplo de Chandigarh (1952) e Brasília (1957), verdadeiros museus modernistas ao ar livre (PELLETIER; DELFANTE, 2000, p. 113).

Mesmo as villes nouvelles francesas, com suas soluções espaciais miraculosas, transformaram-se em espaço para o turismo arquitetônico (WERMES, 1991). Após a iniciativa de criação das cinco CNs no entorno parisiense - Évry, Cergy-Pontoise, Marne-la-Vallée, Melun-Sénart e Saint-Quentin-en-Yvelines -, o Estado promoveu uma sequência de concursos, cada um com diferentes níveis de intervenções, divididos em três grandes grupos: 1) grandes concursos de urbanismo (arquitetura e organização urbana de áreas de 700 a 7 mil moradias); 2) concursos de habitação (áreas de 70 a algumas centenas de moradias); e 3) concursos de espaços públicos. A quantidade de concursos possibilitou uma diversidade de projetos realizados por mais de 260 arquitetos e urbanistas, dos quais se destacam: Ricardo Bofill, Christian de Portzamparc, Jean Nouvel, Alain Sarfati, Tomasz Fiszer, Manuel Nuñez Yanowsky etc. Nesse rico acervo urbanístico e arquitetônico pós-moderno, encontram-se: o Espaço de Abraxas, um complexo residencial composto por três prédios: Teatro, Palácio e Arco, desenhado pelo arquiteto espanhol Bofill em 1982;

${ }^{29}$ Si les villes nouvelles ont souvent été, dans leur pays - ex-URSS, Grande Bretagne, Pays-Bas, Suède, Finlande, France - , des laboratoires en matière d'urbanisme, offrant un milieu de vie plus satisfaisant que les banlieues ordinaires, elles n'ont pas toujours constitué, sur le plan architectural (à l'exception de quelques réalisations isolées comme Tapiola en Finlande), le foyer d'innovation attendu. 
e as Arenas de Picasso, um conjunto de habitação para baixa renda, construído entre 1980 e 1984, elaborado pelo arquiteto Uzbeque Yanowsky.

Inovações e experimentações que chegam ao exagero, como nos projetos para a cidade-satélite dinamarquesa de Albertslund (1963), nos arredores de Copenhague, com a predominância de uma arquitetura mediterrânea; e para a CN chinesa de Gaoqiao, no entorno de Xangai, com sua arquitetura holandesa (MING, 2003). Em ambos, a tentativa de reproduzir, ipsis litteris, ambientes localizados a milhares de quilômetros do sítio de origem - longe, portanto, de seu devido contexto socioambiental - foi o modo encontrado por incorporadores de comercializar arquiteturas historicamente aceitáveis. Assim, o fake arquitetônico e urbanístico se torna moeda imobiliária e o modo de vida, uma indagação: teriam os nativos adquirido as características culturais de gregos ou holandeses?!

Ironias à parte, a programação de CNs é um ato de construção, no abstrato e na realidade, de uma totalidade utópica, coerente com as perspectivas do Estado promotor e assinado por arquitetos-urbanistas ou por outros profissionais. Laboratórios que absorveram fórmulas de experiências, inusitadas ou não, na tentativa de criar uma sociedade ideal inserida num espaço planejado. Experimentações espaciais que fazem das CNs um tipo particular na urbanística. Espaços que buscam, ao menos no início, determinar, modular, regrar os comportamentos sociais de seus habitantes.

\section{Definições-síntese e definições fracionadas}

Por fim, nesse trajeto em busca dos diferentes conceitos aplicados, há definições empregadas com o intuito de qualificar as estruturas que compõem as CNs. Um número extenso de conceituações, como atestou o crítico francês Jean-Louis Cohen (2008), que organizo em duas esferas neste livro: as definições-síntese e as definições fracionadas. As primeiras referem-se à reunião coerente dos elementos compositivos das CNs, enquanto as segundas abrangem leituras pontuais sobre alguns desses elementos, como: terminologias, vontade pública ou privada, funções 
pré-estabelecidas, território, envolvimento profissional, traçado, tamanho populacional, tempo de desenvolvimento, além de atribuições genéricas.

O interesse por uma definição precisa começou a partir de meu primeiro encontro com o professor-urbanista Philippe Panerai, em seu bureau da rue des Feuillantines, em Paris. Ao ser indagado sobre o que seria uma CN, ele prontamente me respondeu:

Uma cidade nova é uma cidade cuja implantação e construção foram geradas por uma decisão, num sítio onde não existia uma cidade, mas ali poderia estar uma vila, um forte, uma usina [...]. (PANERAI, 2007, entrevista, tradução nossa). Uma simples pergunta que, ao ser respondida, instigou-me a vasculhar livros e revistas à procura de respostas equivalentes. ${ }^{30}$

Se, para monsieur Panerai, a vontade, a localização estratégica e a função caracterizam uma $\mathrm{CN}$, outros autores compartilham da mesma ideia, a começar por Françoise Choay e Pierre Merlin (2005) que, em seu Dictionnaire de l'urbanisme et de l'aménagement, definem ville nouvelle como uma "cidade planificada onde a criação foi decidida pela via administrativa”, classificando-a, segundo as funções para qual foi criada, em:

As cidades novas implantadas fora de regiões urbanizadas, para fins industriais (ex-União Soviética), para equilíbrio da rede urbana (Hungria), sobre recursos minerais (company towns do Canadá) [...]. As novas capitais implantadas distantes de grandes aglomerações por razões de políticas de interiorização, de estratégias defensivas, para favorecer o desenvolvimento de regiões pioneiras ou por todas estas razões: Washington, Canberra, Brasília, Islamabad, Abuja etc,

\footnotetext{
30 "Une ville neuve est une ville dont l'implantation et la construction sont créées par décision dans un site où il n'y a pas de ville, mais il peut y avoir un village, un fort, une usine [...]."
} 
são os exemplos mais conhecidos. (CHOAY; MERLIN, 2005, p. 944, tradução nossa). ${ }^{31}$

“Cidade planificada”, que Adauto Lúcio Cardoso exemplifica ao mencionar Brasília em seu texto O urbanismo de Lucio Costa: contribuição brasileira ao concerto das nações, posicionando-a como fruto de um pensamento racional em busca de um ideal:

[...] um ato fundador da racionalidade, que incorpora um território estranho aos domínios do desenvolvimento, imagem de uma nova nacionalidade, e que se transforma em síntese de uma modernização que pode ser purificada de seus problemas, se orientada a partir da intervenção organizadora de um poder racionalizador e normatizador. (CARDOSO, 1996, p. 111).

Planificação, desejo e localização, aspectos aos quais Farhad Atash (2000) adiciona a diversidade dimensional das CNs, variando de "pequenas comunidades coexistindo com áreas urbanas pré-existentes até assentamento de grande escala”; e inclui novas funções específicas, como: “descongestionamento urbano; reavivar economicamente áreas decadentes; oferecer moradias” (ATASH, 2000, p. 68, tradução nossa). ${ }^{32}$

Não bastasse, Pierre Laconte et al. (1982) se unem a esses autores ao delimitarem as CNs a um conjunto urbano planificado, implantado numa área até então agrícola, e refletindo o sistema de valores ideológicos e políticos do promotor, que está tanto no

31 "Les villes nouvelles implantées hors des régions urbanisées, à des fins industrielles (ex-Union soviétique), d'equilibre du réseau urbain (Hongrie), sur des ressources minières (Company Towns du Canada) [...] Les nouvelles capitales implantées à l'écart des grandes agglomérations pour des raisons de politique intérieure, de stratégie défensive, pour favoriser le développement de régions pionnières ou pour plusieurs de ces raisons: Washington (fin du XVIII ${ }^{\text {) }}$, Canberra (années 1920), puis Brasilia, Islamabad, Abuja (Nigeria), etc., en sont les exemples les plus connus.”

32 “[...] petites communautés coexistant avec des zones urbaines préexistantes et des agglomérations à grande échelle [...] décongestion urbaine; faire revivre économiquement des zones décadentes; offrir des habitations [...].” 
setor público (maioria dos casos) como no setor privado, este podendo ser comercial (Columbia, em Maryland, EUA) ou sui generis (Letchworth, Welwyn Garden City, Tapiola, Louvain-la-Neuve, na Bélgica). À leitura do local e da ação promotora é somada uma análise do tempo de desenvolvimento e das estruturas urbanas necessárias:

O caráter planejado da cidade nova, ou de um conjunto urbano, atrai normalmente um fluxo importante de população em um lapso de tempo restrito. Outra característica própria das cidades novas é a necessidade de produzir, em um curto período, um estoque importante de vias, redes diversas e equipamentos sociais. (LACONTE et al., 1982, p. 107). ${ }^{33}$

Nessa breve apreensão, revelo - e atesto por diagnóstico feito a partir de referências analisadas durante a pesquisa - um consenso conceitual marcado pela diversidade de componentes comuns às CNs. Contudo, ao debruçar com mais atenção sobre alguns trabalhos, deparei-me com outros elementos peculiares, como a diferenciação entre CNs e meros loteamentos periféricos.

Tanto Gilles Leloup (1983) quanto Jack Underhill (1983), ao explanarem sobre CNs, além de ressaltar qualidades já citadas, destacam o equilíbrio. Para ambos os autores, as CNs devem ser equilibradas na relação moradia e emprego, algo primordial para distingui-las de meras cidades-dormitórios ou de simples expansões periféricas de uma grande cidade. Pierre Bloc-Duraffour (1998) enfatiza a importância de tal estabilidade na formação de uma identidade para a cidade que surge:

O termo cidade nova deve ser reservado às cidades que preenchem as seguintes condições: um esquema de urbanismo de conjunto, que dá à cidade sua unidade arquitetônica e faz dela uma entidade autônoma,

\footnotetext{
33 "Le caractère planifié de la ville nouvelle ou d'un ensemble urbain attire normalement un flux de population important dans un laps de temps limité. Une autre caractéristique des villes nouvelles est la nécessité de produire, en peu de temps, un stock important de routes, de réseaux divers et d'installations sociales."
} 
notadamente distinta dos assentamentos vizinhos; [...] um nível de equipamento suficientemente completo e uma identidade muito afirmada para que seus cidadãos se reconheçam eles mesmos como habitantes da cidade nova. (BLOC-DURAFFOUR, 1998, p. 88, tradução nossa). ${ }^{34}$

Independência física e cultural que se soma a uma independência econômica e política indispensável, como suscita o International New Towns Institute (INTI):

Cidades novas são assentamentos humanos fundados num certo momento da história por um ato explícito de vontade, de acordo com um plano precedente e objetivando sobreviver como uma comunidade local auto-sustentável e com governo local independente, capaz de desempenhar papel próprio no desenvolvimento de uma região na qual está localizado. (INTI, 2009, tradução nossa). ${ }^{35}$

Discurso similarmente pregado pelo governo iraniano ao estabelecer sua política de criação de CNs. Para ele, as CNs devem ter uma fundação econômica forte, visando a oferecer trabalho e atividades não apenas para sua população como para a população vinda de fora. Também deve ter identidade própria para atuar como polo num nível local e regional (IRAN, 1991).

Com isso, introduzo a síntese de Gideon Golany (1976) ao resumir CNs a partir de cinco elementos: 1) grau de autossustentabilidade; 2) comunidade balanceada; 3) diversidade de funções urbanas; 4) grau de independência política; e 5) tamanho.

\footnotetext{
34 "Le terme ville nouvelle devrait être réservé aux villes qui remplissent les conditions suivantes: un schéma d'urbanisme commun qui confère à la ville son unité architecturale et en fait une entité autonome, se distinguant notamment des localités voisines; [...] un niveau d'équipement suffisamment complet et une identité très affirmée pour que ses citoyens se reconnaissent comme des habitants de la ville nouvelle."

35 "New towns are human settlements founded at a certain moment in history by an explicit act of desire, according to a previous plan and aiming to survive as a self-sustaining local community with independent local government capable of playing its own role in the development of a region in which it is located."
} 
Embora ocorram essas oscilações conceituais - presença ou não de alguns elementos estruturais na definição de CNs -, podemos averiguar uma constância e, com isso, atribuir a esse tipo urbanístico uma unidade a ser particularizada na definição funcional. Unidade que permite a autores receitar o modo de construir uma CN, como faz Rassem Khamaisi (1998) ao propor CNs na Palestina. Segundo o manual estipulado pelo autor, esse empreendimento deve contar com: iniciativa e direção (órgão público especializado); planejamento (plano diretor participativo e flexível, aplicado em etapas); finanças (associação entre público e privado); terra (necessidade de grandes áreas de propriedade pública, mas com permissão de posse para setor privado - atrativo); implementação (governo central e governo local devem agir em conjunto, legislação, fase de desenvolvimento do governo local); e tamanho das novas cidades (resultante de um minucioso estudo de demanda esperada que permita as trocas de serviços e comércio, em torno de 100 mil habitantes).

Delimitações sínteses à parte, concomitantemente foram identificadas as definições fracionadas. Trata-se de olhares pontuais, focados sobre algum dos diferentes aspectos que qualificam as CNs. Estudos que as relacionam: às funções para quais foram criadas, num lado mais filosófico que descritivo; e às fórmulas baseadas no tamanho, na população e no tempo de desenvolvimento.

A diversidade dos princípios e dos objetivos que presidem a concepção de CNs direciona alguns especialistas a se aterem exclusivamente: ou à ordem urbanística (tamanho das cidades, agrupamento, localização, planejamento interno, modelos de habitações predominantes etc.); ou à ordem administrativa (natureza do empreendimento, relação com as coletividades locais); ou à ordem financeira (MERLIN, 1969a). Essa é uma diversidade presente "seja em períodos mais remotos ou mais recentes, e que só pode ser analisada caso a caso”, CN por CN, conforme declarou a historiadora do urbanismo Donatella Calabi (2008, tradução nossa). ${ }^{36}$

36 "Sia per i periodio più lontani che per quelli recenti, un discorso più articolato non può che essere fatto caso per caso [...]" 
Podemos verificar tal diversidade a partir das dezenas de denominações atribuídas e que conectam CNs: ao momento de sua criação (città di fondazione, cidade de nova fundação); ao querer (cidade de vontade, cidade querida, cidade encomendada, cidade plantada, cidade por decreto, introduced capital); a um ideal (cidades socialistas, Terra de Canaã); ao original (cidade partindo do nada, cidade nascida radicalmente nova, navyé goroda, new communities, nuevos pueblos); a um conhecimento (cidade planejada, cidade concebida, cidade inventada, cidade protótipo, cidade projetada); ao traçado (cidade nova aberta, cidade nova fechada, cidade regular, cidade traçada); ao sítio e sua localização (cidade ex nihilo, cidade surgida do nada, cidade-satélite, cidade-sputnik); e ao artificialismo (cidade de proveta, cidade objeto, cidade fabricada). Termos como modoun eg gegida (cidades novas), "utilizado para designar novas comunidades ou novos assentamentos, chamados oficialmente em árabe al tagamoh eg gegida" (JOSSIFORT, 1998, p. 40, tradução nossa). ${ }^{37}$

Uma profusão de terminologias que se intensifica conforme o país. Na França, por exemplo, identificam-se as villes nouvelles créées, ville créée, nouveaux villages, villes neuves e ville idéale (PANERAI et al., 1985).Uma multiplicidade nominativa que induz a uma discussão sobre a diferença entre villes neuves e villes nouvelles que, embora traduzidas como CNs para a língua portuguesa, não apresentam o mesmo significado em francês, ${ }^{38}$ porque "as palavras raramente são inocentes”, como pontuaram Philippe Panerai, Bernard Gendre e Anne-Marie Châtelet (1986, p. 5, tradução nossa). ${ }^{39}$

${ }^{37 “}$ [...] utilisé pour désigner de nouvelles communautés ou de nouvelles colonies, officiellement appelé en arabe al tagamoh eg gegida [...]."

${ }^{38}$ Segundo definição dada por Françoise Choay (1988), nouvelle refere-se àquilo que aparece pela primeira vez, um tipo novo (como as CNs do entorno de Paris, que surgiram como uma nova forma de expansão urbana). Diferencia-se, por suas características novas e inéditas, daquilo tido comumente por neuve, o que acabou de ser feito e ainda não foi utilizado ou o mais recente (em oposição ao velho, ao mais antigo). "Não somente nova (neuve), que denotará o frescor de uma criação ex nihilo, como em muitas cidades e novas vilas (Villeneuve) desde a Idade Média; mas nova (nouvelle), como a Nova Atlantis de Bacon, cujo atributo marca uma radical diferença” (CHOAY, 1988, p. 224, tradução nossa). Uma distinção que podemos traduzir, respectivamente, por cidade novidade e cidade nova.

39 “[...] les mots sont rarement innocents." 
A ambiguidade da expressão ville nouvelle deve-se a razões múltiplas. Segundo Pierre Merlin (1977), a expressão pode referir-se a uma função primária, ou seja, às CNs estratégicas (capitais federais ou estaduais); às CNs ligadas a uma atividade econômica (industrial, turismo, pesquisa etc.); às CNs integradas a uma grande aglomeração, a uma região urbana, buscando organizar seu desenvolvimento. Ville nouvelle tende a designar, também, a importância da operação: uma CN de dezenas de milhares de habitantes (ville neuve) não pode conter os mesmos serviços, equipamentos etc. de uma cidade de centenas de milhares de habitantes (ville nouvelle do entorno parisiense). Ainda, ville nouvelle concentra a ideia de localização, que não poderá ser a mesma de bairros novos, como os de Estocolmo e Amsterdã, que não têm vocação para serem cidades completas e, por isso, devem estar próximos ao centro da cidade-mãe (MERLIN, 1977). Por fim, a geógrafa Márcia Regina de Andrade Mathieu (2008) levanta, a partir de exemplos brasileiros, uma distinção entre villes nouvelles - cidades-satélites do Distrito Federal, como um tipo de expansão das grandes cidades e unidades urbanas economicamente autônomas -, e nouvelles villes - Brasília, como um tipo de cidade ideal.

Sutilezas nominais que demonstram a riqueza do tema ou um leque de significados que varia conforme os elementos compositivos das CNs, dentre eles a vontade em criá-las. Para o geógrafo Jean Brunhes, as CNs "nunca surgiriam sem que alguém as sonhasse e pusesse a seguir toda sua vontade criadora no trabalho de transformar em realidade o seu sonho” (apud TREVISAN, 2003, p. 142).

A iniciativa de criar uma CN é atribuída a diferentes agentes empreendedores, como expõem Françoise Choay e Pierre Merlin (2005). Pode partir tanto de uma empresa privada, como é o caso das new communities americanas, quanto de uma ação social e não lucrativa, como a da Fundação Habitacional (Asuntosäätiö), que empreendeu a construção de Tapiola (1952) e Kivenlahti (1965) na Finlândia. Pode também partir do poder público, seja pela coletividade local, como os novos bairros que constituem as periferias do pós-guerra das cidades holandesas, suecas e de algumas cidades alemãs, seja pelo governo maior, como os casos da União Soviética e Espanha. 
A União Soviética foi o primeiro país do mundo a lançar, após a Revolução de 1917, uma política de CNs em grande escala, como resultado da conjunção de um debate de ideias e de uma política de planejamento do território (MERLIN, 1992). Dessa ação, mais de mil exemplares de navyé goroda (cidades novas) surgiram.

Já os nuevos pueblos, uma das denominações para CNs na Espanha, foram implantados pelo regime ditatorial de Francisco Franco (1892-1975) entre 1936 e 1975. O programa de cidades novas rurais foi um dos mais ambiciosos e criticados planos de CNs no século XX (WEINER, 1981). Concebido pelo Instituto Nacional de Colonização espanhol, planejou e completou mais de 300 CNs entre 1942 e 1973.

Resultantes de uma ação privada ou pública, tais CNs também foram definidas a partir de outro elemento: o envolvimento de profissionais em sua concepção física. Nesse sentido, Donatella Calabi (2008) descreve os diferentes profissionais responsáveis por projetos de CNs ao longo da história. Os astrônomos na Antiguidade foram responsáveis por dominar a organização espacial dos astros e reproduzi-la, pela geometria, em comunidades terrenas. Racionalidade posteriormente adotada pelo clero, na Idade Média, e por engenheiros militares, no Renascimento, que tiraram partido da topografia para implantar suas fortalezas e suas cidades de defesa. Na Era Industrial, as cidades novas vão ser projetadas, principalmente, por engenheiros-arquitetos preocupados em separar as cidades pelo zoning e por normas edilícias como modo de controle da distribuição dos edifícios e de suas funções.

Além da presença de um savoir-faire, a professora também caracteriza a città nuova por sua localização, como um "assentamento surgido do nada em um território substancialmente não urbanizado” (CALABI, 2008)..$^{40}$ Sítios caracterizados por sua localização erma, como as regiões áridas propícias à “inseminação artificial” de novos centros de crescimento (SAFIER, 1977); por sua localização em áreas urbanizadas, como as villes nouvelles implantadas na região metropolitana de Paris; ou por sua localização rural, onde a ação humana se faz presente. Sítios onde o profissional irá traçar sua cidade seguindo referências ali presentes (campos

40 “[...] insediamento realizzato ex novo in un territorio sostanzialmente non urbanizzato." 
agrícolas, divisas, percursos, elementos naturais, estradas vicinais etc.), apropriação que Jean-Louis Cohen (2008) exemplifica pelos novos núcleos urbanos de colonização espanhola implantados sobre antigos assentamentos astecas no México, denominadas, por ele, de CNs pragmáticas.

Após identificação de possíveis lócus, as conceituações pontuais das CNs prosseguem, agora, por um viés funcional, ou uma "ênfase funcional determinada" (FIRMAN, 2004, p. 351, tradução nossa). ${ }^{41}$ Funções ligadas a um determinado momento histórico, como as CNs dos séculos XV e XVII, relacionadas às questões militares, ao desenvolvimento comercial, à ocupação de novas zonas agrícolas, à exibição de um poder soberano, ou a uma prática religiosa (CALABI, 2008). Funções que Michaël Safier (1977) amplia, registrando um nome e respectiva causa: “cidades de reinstalação” (divisão do país, guerra civil, perseguição de minorias, desastres naturais, exploração de recursos naturais em grande escala); “cidades-satélites” (realocação de população de grandes centros urbanos e problemas de moradia); e “cidades novas em sítio obrigado” (abrigar pessoal necessário à gestão e ao funcionamento de estabelecimentos industriais ou administrativos importantes para o plano da vida econômica e política de um país).

Especificamente na União Soviética, Anatole Kopp (apud MERLIN, 1975, p. 10) aborda a questão funcional por meio das cidades socialistas, que foram desenvolvidas em função: do anseio de desenvolvimento industrial, sobretudo em regiões não habitadas - 40\% foram construídas em sítio virgem -; da redistribuição populacional em escala regional, tornando-se cidades-satélites ao redor de grandes aglomerações; da modernização tecnológica do país - como Doubna, um centro tecnológico ao norte de Moscou; Zelenograd, um centro de pesquisa aplicada; e Akademgorodok, um centro científico.

Outro ponto de análise direcionada é o tamanho populacional. Para Françoise Choay e Pierre Merlin (2005), essa dimensão pode variar bastante conforme os exemplares analisados: de alguns milhares de habitantes (cidades de minério canadenses) a mais de um milhão em novas capitais ou em cidades industriais já desenvolvidas (Novosibirsk, na Rússia). O movimento cidade-jardim de Howard

41 “[...] determined functional emphasis [...]." 
previa, no entanto, um tamanho limitado (32 mil habitantes) e a comissão do New Town Act inglês (1946) recomendava entre 20 mil e 60 mil habitantes. Entre 1966 e 1975, a tendência (França, Reino Unido, Holanda, Suécia) estava em criar cidades novas maiores, de 100 mil a 500 mil habitantes. Uma variação de números, que, na maioria das vezes, modifica-se de acordo com o desenvolvimento apresentado pela CN após sua fundação, período no qual a CN se torna uma "cidade normal”, conforme intitulou Pierre Merlin e Michel Sudarskis (1991).

Tempo, entre a origem da CN e a "cidade normal”, ao qual outros autores se atêm para qualificar esse tipo urbanístico. Além do momento preciso de sua fundação, a pós-ocupação também serve de parâmetro para separar CNs e cidades de rápido crescimento, como colocou Nicole Haumont (1997a) ao analisar os exemplares poloneses: “Todas as cidades que têm crescimento rápido são cidades novas? [...] Na Polônia, existem 24 cidades de crescimento rápido, dentre elas somente 3 ou 4 correspondem à definição de cidade nova” (HAUMONT, 1997a, p. 84, tradução nossa). ${ }^{42}$ Para a autora, a diferença está na elaboração de um projeto de urbanismo e na data precisa de fundação das CNs de Jastrzebie, Nowa Huta e Nowe Tychy.

Ademais, estudos específicos sobre CNs revelam aspectos curiosos. Um deles (FIRMAN, 2004) traz o emprego do termo CNs em condomínios fechados de luxo na Indonésia. Esse marketing foi utilizado na região metropolitana de Jacarta, a partir de 1980, quando o governo local propôs essas “CNs” como espaços urbanos de segregação social, idealizados para oferecer segurança e para estabelecer um estilo de vida exclusivo (moderno) a seus habitantes.

Apropriação similar à realizada por Paul Delouvrier na França, ao optar pelo termo ville nouvelle em detrimento a centre urbain nouveau. Para atrair a atenção de novos moradores, traumatizados com os projetos dos grands ensembles (conjuntos habitacionais populares) dos anos 1950, a adoção de um novo nome permitiria o sucesso do empreendimento.

42 “Toutes les villes à croissance rapide sont-elles des villes nouvelles? [...] En Pologne, il y a vingt-et-quatre villes à croissance rapide, dont seulement trois ou quatre correspondent à la définition d'une ville nouvelle." 
Já no Canadá, algo mais intrigante ocorreu: o título de CN era dado após o aparecimento de moradores (BAILLY, 1972). As CNs da província de Alberta, no norte do Canadá, surgiram a partir da descoberta de petróleo na segunda metade do século XX e da exploração de recursos florestais e minerais, o que atraiu um grande contingente populacional para a região. Para contribuir com o crescimento planificado das comunidades petrolíferas, o governo de Alberta instituiu, em 1956, a “Lei sobre as cidades novas”. Não apenas essa medida legislativa favoreceu em 15 anos o surgimento de sete cidades petrolíferas, mas igualmente permitiu o desenvolvimento de cidades minerais, florestais e de aglomeração suburbana. A Lei de 1956 era bem simples: qualquer vila ou cidade cujo crescimento demográfico fosse muito rápido colocaria ao governo provincial sua candidatura a CN. A Comissão Provincial de Planejamento estudaria caso a caso e validaria com um relatório de recomendações. Com a candidatura aceita, o Departamento de Afazeres Municipais se ocupava dos problemas de planejamento da CN e nomeava um conselho de administração. Quando o crescimento e a situação financeira da cidade se estabilizavam, ela perdia seu status de CN para um status de cidade, de vila, ou de uma aldeia, conforme sua população.

Fosse marketing, fosse status, a recorrência às CNs se intensificou durante o século XX, período no qual o meio urbano foi escolhido como habitat do homem contemporâneo. Centenas e centenas de exemplares foram construídos, consolidando CNs como um tipo urbanístico, um modo de produzir espaços urbanos que vários estudiosos definiram cada qual à sua maneira: histórica, comparativa, sintética, fracionada e/ou pontualmente por meio de estudos de casos isolados. Um somatório conceitual para o qual pretendo contribuir ao definir CNs a partir de uma visão pessoal.

\section{Definição funcional}

Quase por encerrar essa etapa longa de nossa viagem, percorrendo os diversos conceitos atribuídos às CNs, peço um fôlego a mais aos leitores para que me 
acompanhem nos pensamentos e ideias expostos a seguir. Elucido a todos que se trata da definição funcional: uma conceituação particular construída para auxiliar a compreensão e a leitura das CNs nesta obra e em trabalhos futuros.

À maneira dos profissionais na virada do século XX, que transpunham vocábulos da medicina para o cerne arquitetônico e urbanístico (por exemplo: intervenção urbana, procedimento projetual, operação urbana, sutura/costura do tecido urbano etc.), como explanou a historiadora Maria Stella Martins Bresciani em palestra ministrada na École des Hautes Études en Sciences Sociales de Paris (6 de fevereiro de 2008), enveredo-me na área da ciência para dela subtrair alguns termos e aplicá-los na definição de CNs. Para enquadrar um núcleo urbano como uma CN, este deve conter traços do DNA ${ }^{43}$ pertinente a essa tipologia urbana. É no DNA da urbe que estarão todas as informações necessárias para a construção da imagem de uma CN. Tais informações serão fornecidas pelos genes, que, no caso das CNs, constituem-se por: desejo, necessidade, lugar, profissional, projeto e tempo. Assim, o DNA de CNs, para esta pesquisa, é formado por seis segmentos alinhavados pelo tempo histórico, cuja mutação pode ocorrer posteriormente conforme o desenvolvimento de pesquisas nessa área.

Contudo, antes de passarmos a um detalhamento maior desse mapa genético, há alguns pontos cujo esclarecimento é oportuno.

O primeiro diz respeito à relação entre CNs e tecidos urbanos existentes. Ao determinar que alguns planos de expansões urbanas qualificam núcleos consolidados como CNs (por exemplo: Santos, Nova York, Barcelona e Boa Vista), em função da proporção entre a área projetada e a área existente, julgo uma CN de expansão aquela cujo novo projeto seja duas vezes, ou mais, maior que a cidade antiga, receba o dobro da população presente, e que tal transformação proporcione uma nova identidade ao núcleo. Entretanto, devo salientar que nem todo ato de espraiamento da

${ }^{43}$ Segundo o sítio eletrônico <www.wikipédia.org>, "o ácido desoxirribonucleico (ADN, em português: ácido desoxirribonucleico; ou DNA, em inglês: deoxyribonucleic acid) é um composto orgânico cujas moléculas contêm as instruções genéticas que coordenam o desenvolvimento e funcionamento de todos os seres vivos [...]. O seu principal papel é armazenar as informações necessárias para a construção das proteínas. Os segmentos de ADN que contêm a informação genética são denominados genes” (Acesso em: 8 out. 2017). 
mancha urbana pode alterar o status de uma cidade de origem espontânea para uma CN. Muito menos que a área expandida seja entendida como uma cidade-satélite.

O bairro de Interlagos em São Paulo - proposto em 1933 como cidade-satélite pelo arquiteto francês Alfred Agache (1875-1959) -, os conjuntos habitacionais dos Institutos de Aposentadoria e Pensão (IAPs), o bairro da Barra da Tijuca no Rio de Janeiro - projetado por Lucio Costa em 1969 -, os condomínios fechados do tipo Alphaville em regiões metropolitanas, os bairros denominados oportunamente de Cidade Nova - como o bairro manauara Cidade Nova de Manaus -, as new towns in-town de Perloff e qualquer outro caso análogo, todos devem ser considerados como unidades urbanas de uma cidade e não CNs.

Não importa qual seja a dimensão ou o número populacional previsto, os exemplos citados não possuem a mesma essência, por exemplo, da cidade-satélite de Taguatinga (1958) e das demais cidades-satélites na órbita do Plano Piloto no Distrito Federal, nas quais há uma clara intenção de criar uma cidade como forma de crescimento urbano. Algo similar ao ocorrido em Paris que, antes das villes nouvelles da década de 1960, recebeu cidades e bairros jardins periféricos nos anos 1930 com o objetivo de oferecer moradias - episódio em que a distinção entre bairros e cidades foi exigência do poder público. Não devemos, portanto, confundir bairros, loteamentos, conjuntos habitacionais, unidades de vizinhança, regenerações urbanas, subúrbios, faubourgs com CNs.

Além dessa distinção, outro ponto refere-se à escala das CNs. Podemos considerar uma vila empresarial no meio da floresta amazônica como uma CN tanto quanto uma cidade construída para um milhão de habitantes nas estepes russas? Na maioria das ocorrências, as CNs são implantadas em áreas isoladas às cidades existentes, formuladas com dimensões de área e tamanho populacional variados.

Fisicamente, as CNs, como toda cidade, são compostas por dois elementos: vias e quadras - podendo as últimas ser divididas em lotes -, que são agenciadas para receber infraestrutura, construções e edificações que atenderão às necessidades de seus habitantes. A forma, seu traçado e seu tecido, ganham desenho a partir de 
condicionantes como o sítio, a função e os ideais de seu criador. Já suas dimensões podem variar conforme a densidade desejada, sendo mais compacta ou mais difusa. Para tal, dois fatores devem ser considerados: o contingente populacional previsto e sua disposição em edificações no espaço intraurbano. Obviamente, o número de habitantes influencia diretamente na dimensão física das CNs, mas seria ele também responsável por determinar aquilo que será ou não uma CN?

Cientes somos das inúmeras delimitações fechadas relacionando número de habitantes ao conceito de cidade. Parte delas define cidade como aquela que possui mais de 2 mil habitantes - tradição da Europa Ocidental -, enquanto outras elevam esse patamar para 20 mil - critérios da Organização das Nações Unidas. Estudiosos defendem que tal critério estatístico e conceituador deve ser estipulado segundo a realidade de cada país, podendo ser 250 habitantes na Dinamarca ou 2,5 mil a 9,9 mil habitantes para as towns ou acima de 10 mil para as cities norte-americanas. No Brasil, segundo órgãos competentes na área (Instituto Brasileiro de Administração Municipal - Ibam; Instituto Brasileiro de Geografia e Estatística - IBGE; e Sistema Nacional de Indicadores Urbanos - SNIU), a classificação é feita a partir da soma da população urbana e rural, sendo considerado município aquele que possuir mais de 2 mil habitantes. ${ }^{44}$

No universo das CNs, tal discussão se faz antiga. Platão, na Antiguidade, estipulou 25 mil a 30 mil habitantes para sua cidade ideal; Leonardo da Vinci, no Renascimento, previu um número aproximado de 30 mil habitantes para sua urbe; e Ebenezer Howard, em fins do século XIX, delimitou 32 mil - sendo 30 mil na zona urbana e o restante na zona rural - para sua cidade-jardim. No século XX, Le Corbusier e Lucio Costa chegaram a um denominador comum de 500 mil habitantes para, respectivamente, Chandigarh e Brasília, contrapondo-se às CNs empresariais africanas de Fria (Guiné, 1957) e Gamba (Gabão, 1969), projetadas para pouco mais de mil habitantes cada. Ademais, saliento que tais números imaginados são

${ }^{44}$ Em 2017, cerca de três em cada quatro municípios brasileiros apresentavam população abaixo de 20 mil habitantes (3.804 cidades num total de 5.570), num universo de 84\% da população brasileira estabelecida em zona urbana. Nesse sentido, temos $68,3 \%$ de brasileiros vivendo em cidades com menos de 20 mil habitantes (IBGE). 
em muito superados com o desenvolvimento das CNs: Goiânia (Goiás), projetada para 50 mil habitantes nos anos 1930, em 1960 já possuía população superior a 150 mil; ou, no sentido inverso, podem ficar aquém da expectativa: Águas de São Pedro (São Paulo), elaborada na década de 1930 para 10 mil habitantes, conta, atualmente, com pouco mais de 2,7 mil. Trata-se, pois, de uma variável instável, que não nos permite estabelecer indicadores conceituais de CNs.

Uma CN pode ter 1 mil ou 1 milhão de habitantes; pode se assemelhar a uma vila ou a uma metrópole; pode ser Belterra (1934), uma das CNs idealizadas pelo norte-americano Henry Ford (1863-1947) em plena floresta amazônica paraense, hoje com aproximadamente 16 mil habitantes; como pode ser Novosibirsk (1926), a CN industrial criada pelo georgiano Josef Stalin (1878-1853) na Sibéria, hoje com 1,5 milhão de habitantes. Seja qual for o número populacional, serão o contexto - a realidade - e a urbanidade o que nos permitirão qualificar uma CN como cidade.

Necessariamente, o isolamento de um núcleo urbano em um determinado território gera nele uma urbanidade. Para tal urbanidade, uma cidade deve apresentar, no mínimo, dois aspectos: possuir uma aglomeração de construções e revelar certos tratados sociais e atividades de relação. Essa urbanidade será responsável por permitir funções de troca, de confrontação e de encontros coletivos, dados num determinado espaço e suportados por uma estrutura equipada para armazenar e transmitir os bens materiais e culturais. No caso das CNs, essa urbanidade é artificial e intencionalmente colocada no momento de sua fundação para que possa atender à população recém-alojada e iniciar um processo de desenvolvimento próprio. Desse modo, todas as CNs, independentemente do número de habitantes e da dimensão física, devem apresentar, ao nascer, um espaço urbanizado que forneça condições necessárias às relações sociais e à interação socioambiental.

Por fim, devemos atentar para a questão político-administrativa. A falta de um poder público - prefeitura e câmara legislativa -, composto desde a origem de um núcleo urbano isolado, não necessariamente impede sua titulação de CN. Embora isso caracterize uma das principais diferenças entre uma cidade e uma vila 
ou um distrito, pode-se permitir uma flexibilidade temporal para que um núcleo urbano, sem governo em seus primórdios, seja considerado uma CN. Nos primeiros anos após a fundação, geralmente o papel administrativo fica a cargo da empresa empreendedora - como fez a Companhia Siderúrgica Nacional com Volta Redonda (Cidade do Aço) entre 1941 e 1968, ano de sua emancipação -, ou mesmo de uma cooperativa sem fins lucrativos - como em Letchworth, cuja gerência inicial coube à First Garden City Ltd. Somente após uma consolidação efetiva - econômica, social e urbana -, tal cidade adquire emancipação com a instauração do município, perdendo seu posto de povoado, de distrito, de vila. Com um governo local próprio, tal CN ganha sua independência - autonomia administrativa -, abrindo campo para o seu desenvolvimento. Tal processo pode ser verificado na história das CNs de Carajás (Pará, 1973) e Caraíba (Bahia, 1976), vilas operárias ligadas a empresas mineradoras e polos atrativos em suas regiões.

A partir desse panorama elucidativo - no qual distingo CNs de meras unidades urbanas, retiro o número populacional e a dimensão física dos seus critérios definidores, revelo a importância de uma urbanidade desde sua fundação, questiono a necessidade de uma autonomia administrativa original -, venho agora apresentar os atributos que, a meu ver, permitem identificar exemplares desse produto urbano.

Inicialmente, as CNs devem conter, em seu passado, um ambiente propício à sua criação. Um contexto, como vimos no capítulo anterior, composto por ideais, sonhos e desejos, somados aqui a conjunturas político-econômico-sócio-culturais favoráveis. Condicionantes que tornarão reais as utopias - utopias físicas -, verdadeiros retratos de determinados períodos históricos.

Na totalidade, teremos um quadro temporal abrangente, permeando períodos distintos e permitindo ao leitor compreender a evolução dessa tipologia urbanística feita a partir do “tempo de longa duração” (BRAUDEL, 1969), que nos possibilita analisar as transformações das estruturas que compõem as CNs ao longo dos séculos. Uma história em ritmo lento, que acolhe, em seu interior, os objetos escolhidos para serem narrados (CNs e seus atributos), levando em conta a marca de sua atração pelo todo. 
Dito isso, resgato a ideia de um DNA comum às CNs, que, necessariamente, deve ser composto por seis segmentos alinhavados por esse "tempo de longa duração”. Tais estruturas genotípicas, subsídios para a identificação de casos de CNs, correspondem a:

1. desejo: vontade do poder público e/ou da iniciativa privada em concretizar essas ações específicas;

2. necessidade: busca em atender, ao menos de início, a uma ou mais funções dominantes (administrativa, de colonização, ferroviária, de realocação, balneária, satélite etc.);

3. lugar: implantação num sítio previamente escolhido;

4. profissional: envolvimento de agente(s) definido(s) - eventualmente profissional(is) habilitado(s) - na sua elaboração física;

5. projeto: existência de um projeto urbanístico; e

6. tempo: presença de um limite temporal determinado, implicando, inclusive, um momento de fundação razoavelmente preciso.

Num primeiro instante, num sincronismo harmônico, três atributos surgem na origem da criação das CNs: o desejo de criá-las, a função para a qual foram inicialmente idealizadas e a escolha de um sítio específico para sua implantação.

O desejo - a vontade - de construir uma CN parte, como veremos em breve, de uma única pessoa ou de um grupo de pessoas apoiados por capital privado e/ou público, responsáveis por gerenciá-la antes, durante e logo após sua fundação. Diretamente relacionada está a função, a necessidade - política, econômica, social e cultural para qual o empreendimento é idealizado - cidades especializadas resultantes de um evento importante. Fechando essa cadeia preliminar está a escolha do sítio, atributo determinante para o surgimento da cidade, com influência direta nas suas atividades político-econômicas. Talvez o sítio seja o motivo que suscitou a iniciativa de sua criação - exploração mineral, entroncamento viário etc. -, ou que dará suporte àquilo 
desejado por seus criadores - por exemplo, defesa de território. Seja causa ou consequência, o sítio juntamente com o desejo e a função formam a base genética das CNs.

Figura 5: DNA

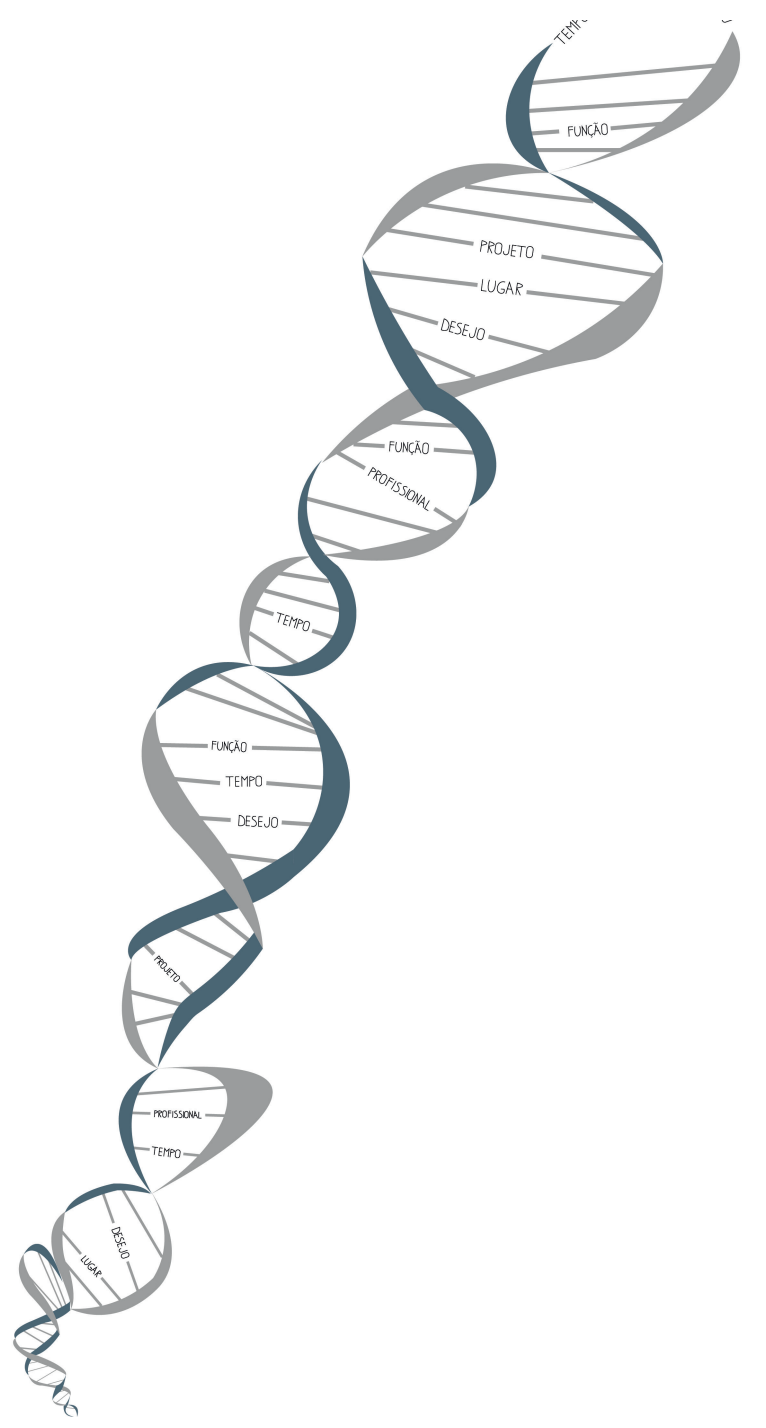


Da teoria à prática, da cidade premeditada à cidade real, entra(m) em cena o(s) profissional(is) que dará(ão) concretude à CN a partir da concepção de seu espaço físico, seja o traçado (vias, quadras e lotes), seja o tecido (parcelamento e edificações). Engenheiros, geógrafos, planejadores, agrimensores, topógrafos, arquitetos e urbanistas, entre outros, elaborarão um projeto para a cidade, com maior ou menor grau de detalhamento, que nos permitirá classificá-la segundo um tipo. O traçado e o tecido original permitem-nos visualizar os tipos urbanísticos e arquitetônicos em voga na época de sua materialização (Zeitgeist), além de identificar características peculiares (elementos fenotípicos).

Completando os cincos atributos está o tempo, o “tempo de curta duração”. Numa CN, o tempo é marcado por três fases: gestacional (decisão, projetação e construção); nascimento (ponto mais ou menos preciso de fundação); e desenvolvimento preliminar (um período curto de consolidação até atingir sua maioridade). Daí em diante, assim como no paradoxo nature versus nurture (natureza versus criação), as CNs podem adquirir vida própria e, eventualmente, deixarem de ser novas.

Por fim, a cadeia dos seis segmentos é combinada pela coluna-vertebral do DNA: o tempo histórico (“tempo de longa duração”). Primeiro, um tempo revelador das condicionantes político-econômico-sócio-culturais de cada época. Segundo, um tempo referencial da evolução histórica desse tipo urbanístico, sendo possível, a partir dele, visualizar as variações ocorridas no desejo, na necessidade, nos níveis de saber dos profissionais envolvidos, nos avanços tecnológicos que propiciam alterações nos tipos de projetos etc. Trata-se do tempo estruturador, unificador e diferenciador das CNs, a linha de constância do DNA.

Com isso, temos uma composição estruturada a fim de atender às necessidades momentâneas, sendo cada uma de suas frações isoladamente pinçada nos próximos capítulos (as paradas), devidamente conceituadas e exemplificadas por estudos de casos nacionais ou internacionais. 